\title{
Analysis of rainfall and temperature time series to detect long-term climatic trends and variability over semi-arid Botswana
}

\author{
Jimmy Byakatonda ${ }^{1,3, *}$, B P Parida ${ }^{1}$, Piet K Kenabatho ${ }^{2}$ and D B Moalafhi ${ }^{2}$ \\ ${ }^{1}$ Department of Civil Engineering, University of Botswana, P/Bag 0061, Gaborone, Botswana. \\ ${ }^{2}$ Department of Environmental Science, University of Botswana, P/Bag 00704, Gaborone, Botswana. \\ ${ }^{3}$ Department of Biosystems Engineering, Gulu University, P.O. Box 166, Gulu, Uganda. \\ *Corresponding author. e-mail: byakatondaj@hotmail.com
}

MS received 14 December 2016; revised 23 May 2017; accepted 24 July 2017; published online 6 March 2018

Arid and semi-arid environments have been identified with locations prone to impacts of climate variability and change. Investigating long-term trends is one way of tracing climate change impacts. This study investigates variability through annual and seasonal meteorological time series. Possible inhomogeneities and years of intervention are analysed using four absolute homogeneity tests. Trends in the climatic variables were determined using Mann-Kendall and Sen's Slope estimator statistics. Association of El Niño Southern Oscillation (ENSO) with local climate is also investigated through multivariate analysis. Results from the study show that rainfall time series are fully homogeneous with 78.6 and $50 \%$ of the stations for maximum and minimum temperature, respectively, showing homogeneity. Trends also indicate a general decrease of 5.8, 7.4 and 18.1\% in annual, summer and winter rainfall, respectively. Warming trends are observed in annual and winter temperature at 0.3 and $1.5 \%$ for maximum temperature and 1.7 and $6.5 \%$ for minimum temperature, respectively. Rainfall reported a positive correlation with Southern Oscillation Index (SOI) and at the same time negative association with Sea Surface Temperatures (SSTs). Strong relationships between SSTs and maximum temperature are observed during the El Niño and La Niña years. These study findings could facilitate planning and management of agricultural and water resources in Botswana.

Keywords. Correlation; El Niño; homogeneity test; intervention analysis; persistence; trend analysis.

\section{Introduction}

Increasing concentrations of atmospheric carbondioxide $\left(\mathrm{CO}_{2}\right)$ over the recent past has been singled out as the main cause of global warming (Shifteh Some'e et al. 2012; Stocker et al. 2013). The fifth assessment report (AR5) of the intergovernmental panel on climate change (IPCC) shows a close positive association between $\mathrm{CO}_{2}$ concentration and global temperature rise (Stocker et al.
2013). It is reported that the first decade of the 21st century has been the warmest ever, coinciding with the strongest El Niño in 100 years (Stocker et al. 2013; Hansen et al. 2016; Rahman and Lateh 2017). Also climate change projections have revealed a global temperature rise of about $2^{\circ} \mathrm{C}$ in the near future and $4-6^{\circ} \mathrm{C}$ in the long run (Pachauri and Reisinger 2007). These climatic changes could lead to a shift in meteorological variables such as rainfall and temperature (Yue and 
Hashino 2003; Costa and Soares 2009b; Hänsel et al. 2016). Besides, these anticipated changes are not uniformly spread globally, with different regions experiencing impacts at varying degrees. It is further projected that arid and semi-arid regions could experience higher than global average warming levels (Modarres and da Silva 2007; Khan et al. 2016). Hence, there is need to shift focus towards semi-arid locations where adaptation measures to these extreme weather conditions are a big challenge. Studies on long-term changes in rainfall and temperature are necessary for sustainable land and water resources planning and management especially under climate variability and change (Shahid 2010; Tabari and Talaee 2011). Therefore, for any meaningful study on climate variability and change, these meteorological variables may not be ignored. Of recent, interest has increased in investigating long-term trends in rainfall and temperature in quest of tracing the climate change signal (Menzel et al. 2006; Giorgi and Lionello 2008; Kenabatho et al. 2012).

Several studies have since been conducted globally and regionally to investigate climate variability by analyzing trends in rainfall and temperature time series. Such of these investigations have been conducted in semi-arid locations in Iran by Shifteh Some'e et al. (2012) and Tabari and Talaee (2011). Results from their studies indicate both increasing and decreasing trends in meteorological variables for a period of 1966-2006, with significant trends mainly observed during winter period. In Nigeria, Akinsanola and Ogunjobi (2015) reported decreasing trends in both annual and winter seasonal rainfall while using the MannKendal (MK) test statistic. In Portugal, Costa and Soares (2009a) reported high rainfall variability by examining trends in aridity and standardized precipitation index (SPI). Their study found high climatic uncertainty in the south of the country. In Turkey, Partal and Kahya (2006) applied the MK test and Sen's Slope estimator to study the direction and magnitude of trends in meteorological variables. Their study identified the months of January, February and September to be exhibiting decreasing trends especially in the south and west of Turkey for the period from 1929 to 1993. Climatic changes for a period of 1980-2010 were investigated in Serbia by Gocic and Trajkovic (2013) using the MK trend analysis and Sen's Slope estimator. The results indicated increasing trends in both annual and seasonal temperature with no significant trends in rainfall.
Climate variability has also been closely linked with El Niño Southern Oscillation (ENSO) that is attributed to hydro-climatic extremes in form of droughts and floods. ENSO is the main source of climate variability in the Equatorial Pacific (Morán-Tejeda et al. 2016). This climate variability has tele-connections with the Indian and Atlantic Oceans (Nicholson et al. 2001; Nyenzi and Lefale 2006). Influences of ENSO on the local climate may not be ignored since a number of studies over southern Africa have reported its close association with rainfall patterns and onset of droughts (Nicholson et al. 2001; Usman and Reason 2004; Edossa et al. 2014). This study, thus proposes to investigate the association between ENSO and the local climate.

To investigate the temporal and spatial extent of climate variability and change, Botswana, which is located in the mid-latitudes and classified as semiarid, is selected as a study area. Botswana's economy is heavily dependent on the climatic regime since majority of her water resources are derived from rainfall stored in surface reservoirs (Statistics Botswana 2009). Also $80 \%$ of the dwellers in the study area are engaged in rain fed agriculture, which is heavily moderated by the local climate (Batisani 2012; Statistics Botswana 2015). It is therefore necessary to investigate climate variability and change in Botswana since any negative impacts may propagate to other sectors of the economy. Some attempts have been made to study climate variability and change in Botswana by Parida and Moalafhi (2008) and Batisani and Yarnal (2010), who both reported decreasing rainfall and increasing incidences of drought over the study area. However, these studies only analysed rainfall as the only precursor of climate variability and change. With reported global warming, temperature will require inclusion if any conclusive climate change studies are to be conducted. Besides, it is prudent to periodically monitor climate variability and change using location specific meteorological data in order to achieve sustainable management of water and agricultural resources since the climatic regime could change depending on prevailing circumstances. It is on these premises that this study investigates climate variability and change in Botswana. The variability will be studied by investigating homogeneity and trends in rainfall, minimum and maximum temperature from 14 synoptic stations spread across the study area. Also the study intends to determine the degree of association between local climatic variables and ENSO. 
The analysis is proposed to be conducted for both annual and seasonal scales.

\section{Data and methods}

\subsection{Data}

Data used in this study comprises locally observed monthly rainfall, maximum and minimum temperature. The second dataset is from large-scale climatic predictors in the form of sea surface temperatures (SSTs) and southern oscillation index (SOI) elements of ENSO activities in the equatorial Pacific.

\subsubsection{Local meteorological data}

Local meteorological data recorded at 14 synoptic stations as shown in figure 2, was obtained from the Department of Meteorological Services (DMS) of Botswana. The records were of varying length with the longest record being 1960-2014 and the shortest spanning 2000-2014. Details of the stations, annual rainfall coefficient of variations (Cvs) and data record length are presented in table 1. Stations are selected based on the availability of complete data that include rainfall, maximum and minimum temperature with $<5 \%$ missing values.

\subsubsection{Sea surface temperatures and southern oscillation index}

Records of SSTs from El Niño in region 3.4 were obtained from the climatic prediction center of NOAA (NOAA-NCEP 2016). The data record length corresponded to the locally observed meteorological records. Similarly, data on SOI was obtained from the national climate data center of NOAA (NOAA-NCDC 2016). Climatic data analysis is done at annual and seasonal scales. Annual and seasonal averages were obtained from climatic data arranged at monthly scale for the case of temperature time series, while annual and seasonal totals are used for rainfall time series. Seasons considered in this study are summer (October-March) and winter (May-August).

\subsection{Methods}

For analysis of long-term climate variability over the study area, a number of statistical procedures are employed in this study. The steps of analysis involve: (i) applying four absolute tests for homogeneity in the time series; (ii) applying the Mann-Kendall (MK) trend analysis test and Sen's Slope estimator; (iii) detection of persistence and testing its effect on the MK trend statistics, and (iv) assessing the influence of ENSO on local climatic variables.

\subsubsection{Tests for homogeneity}

Data used in long-term climatological studies are required to be homogeneous in that, they should belong to the same population with mean of no temporal variation (Akinsanola and Ogunjobi 2015). Data is considered homogeneous if any changes are only attributed to natural

Table 1. Station locations and length of meteorological variable record.

\begin{tabular}{|c|c|c|c|c|c|c|c|c|c|}
\hline \multirow[b]{2}{*}{ Sl. no. } & \multirow{2}{*}{$\begin{array}{c}\text { Station } \\
\text { ID }\end{array}$} & \multirow{2}{*}{$\begin{array}{c}\text { Station } \\
\text { name }\end{array}$} & \multirow{2}{*}{$\begin{array}{c}\text { Latitude } \\
{ }^{\circ} \mathrm{S} \\
\end{array}$} & \multirow{2}{*}{$\begin{array}{c}\text { Longitude } \\
{ }^{\circ} \mathrm{E}\end{array}$} & \multirow{2}{*}{$\begin{array}{l}\text { Elevation } \\
\text { amsl }(\mathrm{m})\end{array}$} & \multirow{2}{*}{$\begin{array}{l}\text { Rainfall } \\
\mathrm{CV}(\%)\end{array}$} & \multicolumn{3}{|c|}{ Period of record } \\
\hline & & & & & & & Rainfall & Max temp & Min temp \\
\hline 1 & 033-FRAN & Francistown & 21.2 & 27.5 & 968 & 36.7 & 1960-2014 & 1960-2014 & 1960-2014 \\
\hline 2 & 039-GANT & Ghanzi & 21.7 & 21.6 & 1131 & 39.6 & $1960-2014$ & $1961-2014$ & 1960-2014 \\
\hline 3 & 053-JWAN & Jwaneng & 24.6 & 24.8 & 935 & 29.8 & 1988-2014 & 1989-2014 & 1989-2014 \\
\hline 4 & 064-KASA & Kasane & 17.8 & 25.2 & 960 & 26.0 & 1968-2014 & $1983-2014$ & 1983-2014 \\
\hline 5 & 093-LET2 & Letlhakane & 21.3 & 25.3 & 991 & 35.9 & 1993-2014 & $1994-2014$ & 1994-2014 \\
\hline 6 & 106-MAHA & Mahalapye & 23.1 & 26.8 & 1005 & 33.5 & $1960-2013$ & $1971-2014$ & 1971-2014 \\
\hline 7 & 130-MAUN & Maun & 19 & 23.4 & 945 & 38.6 & 1960-2014 & $1965-2014$ & $1965-2014$ \\
\hline 8 & 183-PAN2 & Pandamatenga & 17.8 & 28.6 & 1071 & 29.4 & 1998-2014 & 1998-2014 & 1998-2014 \\
\hline 9 & 213-SEL2 & Selibe-Phikwe & 23.1 & 37.8 & 892 & 34.5 & 1998-2014 & $2000-2014$ & 2000-2014 \\
\hline 10 & 223-SHAK & Shakawe & 18.4 & 21.9 & 1030 & 31.5 & $1960-2014$ & $1965-2014$ & 1965-2014 \\
\hline 11 & 035-SSKA & SSKA & 24.7 & 25.9 & 975 & 34.2 & 1985-2014 & $1985-2014$ & 1985-2014 \\
\hline 12 & 033-SUAP & Sowa Pan & 20.6 & 26 & 908 & 40.4 & 1992-2010 & $2000-2014$ & 2000-2014 \\
\hline 13 & 244-TSAB & Tsabong & 26 & 22.4 & 960 & 42.4 & 1960-2011 & $1961-2014$ & 1961-2014 \\
\hline 14 & 251-TSHA & Tshane & 24 & 21.6 & 1118 & 42.0 & 1960-2014 & $1961-2014$ & 1960-2014 \\
\hline
\end{tabular}


occurrences. Homogeneity testing in this study involves a number of stages. The first stage comprises data quality checks to identify recording errors both visual and graphical techniques. The second stage involves applying of absolute homogeneity testing techniques that include the Standard Normal Homogeneity Test (SNHT; Alexandersson 1986), Pettit test (Pettit 1979), Buishand range test (Buishand 1982) and the Von Neumann ratio test (Von Neumann 1941). Wijngaard et al. (2003), in a comprehensive study of European climate systems, recommended no discarding of stations with suspected inhomogeneities, but rather classify them. Absolute tests were selected over relative tests due to the somewhat sparse and skewed towards the east (figure 2) meteorological network across the study area. Stations are categorized as 'useful', 'doubtful', or 'suspect' following a classification suggested by Wijngaard et al. (2003) and Hänsel et al. (2016). This classification was applied at $1 \%$ level of statistical significance. A station is classified as 'useful' if it is homogeneous in at least three of the tests, 'doubtful' if homogeneity is reported for two tests and 'suspect' when station fails in three or more of the tests (Wijngaard et al. 2003; Costa and Soares 2009b; Hänsel et al. 2016). For further studies of variability and trend analysis, complete data record is used for the stations classified as 'useful'. If a station is labeled 'doubtful', the whole data record is used, but trend in the data is further scrutinized by comparing with trends before and after the suspected year of intervention. For stations classified as 'suspect', the record before the suspected year of intervention was excluded from the analysis. The null hypothesis for the four absolute tests assumes that the time series are homogeneous. For the alternative hypothesis, the SNHT, Pettit and Buishand tests suppose an intervention in the time series. These tests are able to locate the year of intervention and its statistical significance. The Von Neumann test under the alternative hypothesis assumes persistence in the time series. Formulations of the four tests are presented below.

Standard normal homogeneity test (SNHT). The SNHT as presented by Alexandersson (1986) and (Alexandersson and Moberg 1997) gives a statistic that compares the means of the first $m$ series with the last $(n-m)$ series of meteorological variable at an annual scale. If $W_{i}$ denotes meteorological time series for $i=1,2,3, \ldots, n$, then the test statistic is given by
$T(m)=m \bar{y}^{2}+(n-m){\overline{y_{2}}}^{2} \quad$ for $m=1,2, \ldots, n$

where

$$
\overline{y_{1}}=\frac{1}{m} \sum_{i=1}^{m} \frac{\left(W_{i}-\bar{W}\right)}{\sigma}
$$

and

$$
\overline{y_{2}}=\frac{1}{(n-m)} \sum_{i=m+1}^{n} \frac{\left(W_{i}-\bar{W}\right)}{\sigma},
$$

$\bar{W}$ and $\sigma$ are the expected value and standard deviation of the time series, respectively. A plot of $T(m)$ against $m$ reaches its maximum at the suspected year of intervention. The test statistic at the suspected point is given by

$$
T_{0}=\underbrace{\operatorname{Max}}_{1 \leq m \leq n} T(m) .
$$

The null hypothesis is rejected, if $T_{0}$ exceeds a given threshold, which is a function of the sample size at a given level of significance. A table of critical $T_{0}$ values is presented in Wijngaard et al. (2003).

Pettit test. This is a non-parametric rank based test presented by Pettit (1979) and applied in Akinsanola and Ogunjobi (2015) and Wijngaard et al. (2003). It states that if $r_{1}, r_{2}, \ldots, r_{n}$ are ranks of a given meteorological variable $W_{i}$, then the order statistic is given by

$X_{m}=2 \sum_{i=1}^{m} r_{i}-m(n+1) \quad$ for $m=1,2, \ldots, n$

If intervention is suspected to occur at year $K$, the plot of $X_{m}$ against time will exhibit a minimum or maximum at $m=K$ and

$$
X_{K}=\underbrace{\operatorname{Max}}_{1 \leq m \leq n}\left|X_{m}\right| .
$$

The significant values of $X_{K}$ are provided in tables as a function of sample size at a given significant level.

Buishand test. The Buishand test as presented by Buishand (1982) utilizes adjusted partial sums given by 
and

$$
S_{0}^{*}=0
$$

$$
S_{m}^{*}=\sum_{i=1}^{m}\left(W_{i}-\bar{W}\right) \quad \text { for } m=1,2, \ldots, n .
$$

The null hypothesis is accepted, if the plot of $S_{m}^{*}$ against time fluctuates around $S_{0}^{*}$. Gradual rise or fall in the plot is an indication of suspected point of intervention corresponding to a particular year $M$. The test of significance is achieved through rescaled range $R$ given by

$$
R=\left(\frac{\underbrace{\operatorname{Max}}_{1 \leq m \leq n} S_{m}^{*}-\underbrace{\operatorname{Min}}_{1 \leq m \leq n} S_{m}^{*}}{\sigma}\right) .
$$

The critical values of $R / \sqrt{n}$ are given in Buishand (1982). If the computed $R / \sqrt{n}$ is greater than the tabulated value, then the null hypothesis is rejected.

Von Neumann test. The Von Neumann test is a complementary test to the three preceding homogeneity tests characterized by ratios of successive mean square difference to the variance of the time series (Von Neumann 1941; Wijngaard et al. 2003). It is given by

$$
N=\frac{\sum_{i=1}^{n-1}\left(W_{i}-W_{i+1}\right)^{2}}{\sum_{i=1}^{n}\left(W_{i}-\bar{W}\right)^{2}}
$$

The test gives no information on the point of intervention even though it exists. Significant values of $N$ are tabulated in Von Neumann (1941).

\subsubsection{Trend analysis of meteorological time series}

Following classification of meteorological stations as 'useful', 'doubtful', and 'suspect' in section 2.1.1, analysis of trend is made. This study applies two non-parametric statistics, the Mann-Kendall to determine the direction of the trend and Sen's Slope for the magnitude of the trend. The Sen's Slope is also used to determine the percentage change in the variable for the period of analysis.

Mann-Kendall (MK) trend statistic. The MK statistic as presented by Mann (1945) and
Kendall (1975), applied in Tabari et al. (2011) and Akinsanola and Ogunjobi (2015) and is given by:

$$
S=\sum_{i}^{n-1} \sum_{k=i+1}^{n} \operatorname{Sgn}\left(W_{k}-W_{i}\right) \text { for } k>i
$$

where Sgn is the sign function given by

$\operatorname{Sgn}\left(x_{j}-x_{i}\right)=\left\{\begin{aligned}+1 & \text { if }\left(W_{k}-W_{i}\right)>0 \\ 0 & \text { if }\left(W_{k}-W_{i}\right)=0 \\ -1 & \text { if }\left(W_{k}-W_{i}\right)<0\end{aligned}\right.$

The statistical significance of the trend is tested using the $Z$-statistic which is obtained from

$$
Z_{w}= \begin{cases}\frac{S-1}{\sqrt{\operatorname{Var}(S)}} & \text { if } S>0 \\ 0 & \text { if } S=0 \\ \frac{S+1}{\sqrt{\operatorname{Var}(S)}} & \text { if } S<0\end{cases}
$$

where $\operatorname{Var}(S)$ is the variance of the $S$ statistic obtained from equation 10. The $\operatorname{Var}(S)$ is computed from

$$
\begin{aligned}
& \operatorname{Var}(S) \\
& \quad=\frac{n(n-1)(2 n+5)-\sum_{i=1}^{q} p_{i}\left(p_{i}-1\right)\left(2 p_{i}+5\right)}{18}
\end{aligned}
$$

where $q$ and $p_{i}$ are the total number of tied groups and ties of extend $i$, respectively. Positive values of $Z_{w}$ designate upward trends, while negative values otherwise. The null hypothesis assumes that no trend exists in the time series and the alternative hypothesis assumes trend exists. The significance of the trend is tested by comparing the resulting $p$-value with a significant value $\alpha$. When the computed $p$-value is greater than $\alpha$, the null hypothesis is accepted. For this study, $\alpha=0.05$ is used. The MK test has successfully been applied in a number of hydro-climatic studies (Shifteh Some'e et al. 2012; Gocic and Trajkovic 2013; Sabzevari et al. 2015).

Trend slope magnitude estimation. The Sen's Slope method is used to test the magnitude of the MK trend. This method examines whether the regression slope between ordered pairs is significantly different from zero. The slope is estimated from the procedure proposed by Thiel (1950) and Sen (1968). The slope of $N$ ordered pairs of data points is given by 


$$
Q_{i}=\frac{\left(W_{k}-W_{i}\right)}{k-i} \quad \text { for } \mathrm{i}=1,2, \ldots, N .
$$

The median slope of $Q_{i}$ arranged in ascending order gives the Sen's Slope and computed from

$$
Q_{\text {med }}=\left\{\begin{array}{ll}
Q_{\frac{(N+1)}{2},}, & \text { if } N \text { is odd } \\
\frac{Q_{\left(\frac{N}{2}\right)}+Q_{\frac{[N+2]}{2}}}{2}, & \text { if } N \text { is even }
\end{array} .\right.
$$

For trend comparison among different meteorological locations, the percentage change in slope is preferred as proposed by Yue and Hashino (2003) and applied in Akinsanola and Ogunjobi (2015) is given by

$$
\Delta S=\frac{Q_{\text {med }} \times T}{\bar{W}} \times 100 .
$$

For regionalization, the total change over the study area is obtained from

$$
\Delta S_{R}=\frac{1}{b} \sum_{i=1}^{b} \Delta S
$$

where $\Delta S$ is the percentage change over a period of record $T, b$ is the total number of stations over the study area and $\Delta S_{R}$ is the regionalized change in a given meteorological variable.

\subsubsection{Detection of persistence}

Parametric trend tests of climatological data series require that it is serially independent and random in nature (Tabari et al. 2011; Gocic and Trajkovic 2013). An auto-correlation is applied to detect non-randomness in data. Presence of persistence in the time series increases chances of accepting the null hypothesis even when trend exists (Yue et al. 2002; Tabari and Talaee 2011). For meteorological time series that exhibits significant serial correlation at $\alpha=0.05$, the effective sample size (ESS) method suggested by Lettenmaier (1976) and used in Tabari and Talaee (2011) and Akinsanola and Ogunjobi (2015) to correct the influence of the serial correlation on the Mann-Kendall test is applied.

The auto-correlation lag-1 is used in this study, since the main interest is to examine the possibility of none randomness in the data series. Possibility of statistically significant correlations in sample data series $W_{1}+W_{2}+W_{3}+\cdots+W_{n}$ is tested using the following procedures as stated in Gocic and Trajkovic (2013)
- The lag-1 serial correlation coefficient of sample data $W_{i}$ is computed as applied in Croakin and Tobias (2006)

$$
r_{1}=\frac{\frac{1}{n-1} \sum_{i=1}^{n-1}\left(W_{i}-\bar{W}\right)\left(W_{i+1}-\bar{W}\right)}{\frac{1}{n} \sum_{i=1}^{n}\left(W_{i}-\bar{W}\right)^{2}}
$$

- If the computed $r_{1}$ in $(i)$ above is not significant at $\alpha=0.05$, the variance of the Mann-Kendall is used as earlier determined in equation (14).

- Should the calculated $r_{1}$ be significant at $\alpha=0.05$, the variance of the Mann-Kendall statistic is modified using ESS.

The modified variance $\operatorname{Var}^{*}(s)$ is given by

$$
\operatorname{Var}^{*}(s)=\operatorname{var}(s) \cdot \frac{n}{n^{*}}
$$

where $n$ is the actual sample size of the time series and $n^{*}$ is the ESS. The ratio of $n / n^{*}$ is the correction factor. Matalas and Langbein (1962) and Akinsanola and Ogunjobi (2015) proposed a formula to determine $n^{*}$ for the lag-1 serial correlation

$$
n^{*}=\frac{n}{1+2\left(\frac{r_{1}^{n+1}-n r_{1}^{2}+(n-1) r_{1}}{n\left(r_{1}-1\right)^{2}}\right)}
$$

by replacing the $\operatorname{Var}^{*}(s)$ with $\operatorname{Var}(s)$ in the MannKendall's equation, a modified test statistic $Z_{w}$ is computed by

$$
Z_{w}^{*}=Z_{w} \sqrt{\frac{n^{*}}{n}} .
$$

The null hypothesis being tested is that, the sequence was produced in a random manner.

\subsection{Influence of ENSO on local climatic variables}

El Niño southern oscillation (ENSO) defines climatic patterns in the Equatorial Pacific. ENSO is comprised of two components: El Niño and La Niña. El Niño is associated with warm SSTs in the Equatorial Pacific that coincide with negative SOI, whereas La Niña is closely linked to cool SSTs and positive SOI (Rojas et al. 2014). The degree of association between ENSO and local climatic variables is investigated using multivariate analysis. Monthly SSTs and SOI data are averaged at annual and seasonal scales using the same criteria as that of meteorological variables. Correlations between SSTs and climatic variables on one hand and SOI, on the other hand, are performed. 


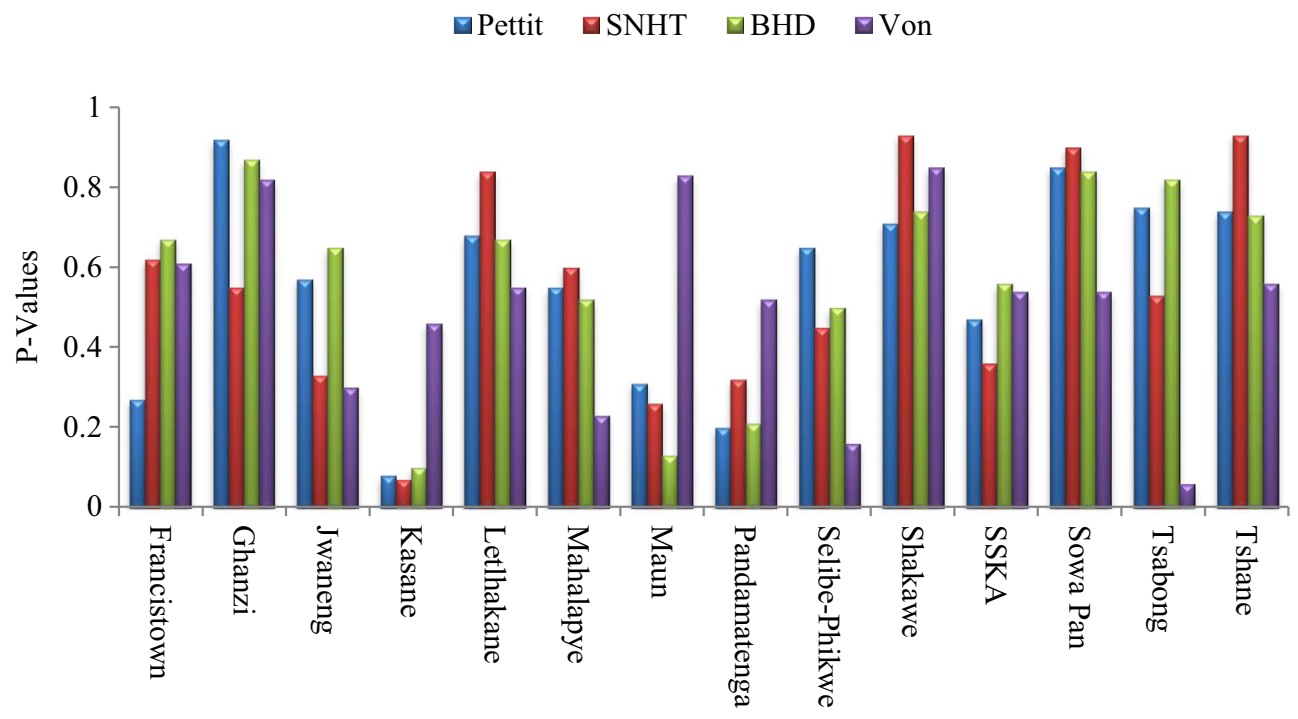

Stations

Figure 1. p-values from four homogeneity tests on annual rainfall time series.

Table 2. P-values from four homogeneity tests and probable year of intervention for maximum temperature.

\begin{tabular}{|c|c|c|c|c|c|c|c|c|}
\hline Station & $\begin{array}{l}\text { Pettit's } \\
\text { test }\end{array}$ & $\begin{array}{c}\text { Change } \\
\text { year }\end{array}$ & SNHT & $\begin{array}{c}\text { Change } \\
\text { year }\end{array}$ & $\begin{array}{c}\text { BHD's } \\
\text { test }\end{array}$ & $\begin{array}{c}\text { Change } \\
\text { year }\end{array}$ & $\begin{array}{c}\text { Von's } \\
\text { test }\end{array}$ & Classification \\
\hline Francistown & 0.00 & $1980 / 81$ & 0.00 & $1980 / 81$ & 0.00 & $1980 / 81$ & 0.04 & Suspect \\
\hline Ghanzi & 0.05 & Homo & 0.09 & Homo & 0.04 & Homo & 0.26 & Useful \\
\hline Jwaneng & 0.79 & Homo & 0.84 & Homo & 0.92 & Homo & 0.45 & Useful \\
\hline Kasane & 0.04 & Homo & 0.02 & Homo & 0.02 & Homo & 0.18 & Useful \\
\hline Letlhakane & 0.78 & Homo & 0.87 & Homo & 0.70 & Homo & 0.43 & Useful \\
\hline Mahalapye & 0.05 & Homo & 0.02 & Homo & 0.04 & Homo & 0.20 & Useful \\
\hline Maun & 0.00 & $1980 / 81$ & 0.00 & $1980 / 81$ & 0.00 & $1980 / 81$ & 0.04 & Suspect \\
\hline Pandamatenga & 0.75 & Homo & 0.81 & Homo & 0.81 & Homo & 0.75 & Useful \\
\hline Selibe-Phikwe & 0.42 & Homo & 0.55 & Homo & 0.53 & Homo & 0.71 & Useful \\
\hline Shakawe & 0.00 & $1980 / 81$ & 0.00 & $1980 / 81$ & 0.00 & $1980 / 81$ & 0.00 & Suspect \\
\hline SSKA & 0.23 & Homo & 0.26 & Homo & 0.18 & Homo & 0.18 & Useful \\
\hline Sowa Pan & 0.76 & Homo & 0.72 & Homo & 0.58 & Homo & 0.45 & Useful \\
\hline Tsabong & 0.15 & Homo & 0.36 & Homo & 0.15 & Homo & 0.44 & Useful \\
\hline Tshane & 0.10 & Homo & 0.13 & Homo & 0.05 & Homo & 0.33 & Useful \\
\hline
\end{tabular}

Statistically significant at $\alpha=0.01$, Homo $=$ Homogeneous.

\section{Results}

Results from the four absolute homogeneity tests, trend analysis test, tests for persistence and influence of ENSO on local climate are presented in this section. The results are for both annual and seasonal (summer and winter) timescales.

\subsection{Tests for homogeneity}

\subsubsection{Annual rainfall time series}

Figure 1 presents homogeneity test results on annual rainfall totals. The $p$-values are compared with a value of $\alpha=0.01$. The results reveal that the $p$-values at all stations in the study area are above the significant value and hence homogeneous. They are all classified as 'useful' to be used for further trend and variability analysis.

\subsubsection{Annual maximum temperature time series}

$P$-values from homogeneity tests of maximum temperature series are presented in table 2. Results reveal that majority of the stations are homogeneous except for three stations that failed three out of the four tests and hence classified as 'suspect'. These stations include Francistown, in the east; 
Table 3. P-values from four homogeneity tests and probable year of intervention for minimum temperature.

\begin{tabular}{|c|c|c|c|c|c|c|c|c|}
\hline Station & $\begin{array}{l}\text { Pettit's } \\
\text { test }\end{array}$ & $\begin{array}{c}\text { Change } \\
\text { year }\end{array}$ & SNHT & Year & $\begin{array}{c}\text { BHD's } \\
\text { test }\end{array}$ & $\begin{array}{c}\text { Change } \\
\text { year }\end{array}$ & $\begin{array}{c}\text { Von's } \\
\text { test }\end{array}$ & Classification \\
\hline Francistown & 0.07 & Homo & 0.04 & Homo & 0.02 & Homo & 0.00 & Useful \\
\hline Ghanzi & 0.00 & $1984 / 85$ & 0.06 & Homo & 0.00 & $1984 / 85$ & 0.01 & Suspect \\
\hline Jwaneng & 0.07 & Homo & 0.13 & Homo & 0.01 & Homo & 0.03 & Useful \\
\hline Kasane & 0.00 & $1992 / 93$ & 0.00 & $1992 / 93$ & 0.00 & $1992 / 93$ & 0.00 & Suspect \\
\hline Letlhakane & 0.01 & Homo & 0.12 & Homo & 0.01 & Homo & 0.01 & Useful \\
\hline Mahalapye & 0.00 & $1981 / 82$ & 0.00 & $1981 / 82$ & 0.00 & $1981 / 82$ & 0.00 & Suspect \\
\hline Maun & 0.00 & $1983 / 84$ & 0.00 & $1983 / 84$ & 0.00 & $1983 / 84$ & 0.00 & Suspect \\
\hline Pandamatenga & 0.87 & Homo & 0.06 & Homo & 0.42 & Homo & 0.12 & Useful \\
\hline Selibe-Phikwe & 0.32 & Homo & 0.22 & Homo & 0.51 & Homo & 0.05 & Useful \\
\hline Shakawe & 0.01 & Homo & 0.02 & Homo & 0.01 & Homo & 0.00 & Useful \\
\hline SSKA & 0.35 & Homo & 0.00 & $1986 / 87$ & 0.18 & Homo & 0.01 & Doubtful \\
\hline Sowa Pan & 0.20 & Homo & 0.41 & Homo & 0.37 & Homo & 0.05 & Useful \\
\hline Tsabong & 0.00 & $1996 / 97$ & 0.00 & $1997 / 98$ & 0.00 & $1996 / 97$ & 0.00 & Suspect \\
\hline Tshane & 0.00 & $1988 / 89$ & 0.00 & $1988 / 89$ & 0.00 & $1988 / 89$ & 0.00 & Suspect \\
\hline
\end{tabular}

Statistically significant at $\alpha=0.01$, Homo $=$ Homogeneous.

Maun in the north and Shakawe, in the northwest. At all the stations, the suspected year of intervention is $1980 / 81$.

\subsubsection{Annual minimum temperature time series}

Results from tests of homogeneity in minimum temperature are presented in table 3 . These results reveal that at $50 \%$ of the stations minimum temperature series are homogeneous. At SSKA, the minimum temperature series failed two tests and hence classified as 'doubtful'. The change year reported at this station is $1986 / 87$. Forty-three percent of the stations failed in at least three of the tests and are classified as suspect. These stations are Ghanzi with a change year of $1984 / 85$, Kasane with a change at 1992/93 and Mahalapye at $1981 / 82$. The Other stations are Maun at $1983 / 84$, Tsabong at $1996 / 97$ and Tshane at $1988 / 89$.

\subsection{Mann-Kendall (MK) trend analysis and percentage change}

Trend statistics in annual, summer and winter trends for rainfall, maximum and minimum temperature are presented in tables $4-6$. The period of trend analysis is indicated especially for stations classified as 'doubtful' or 'suspect', where all the data record length were not used in the analysis.

\subsubsection{Rainfall trends and percentage changes}

Trends in annual rainfall. Results from the MK trends and Sen's Slope estimator are presented in table 4. Both increasing and decreasing trends are experienced over the study area though none was significant at $\alpha=0.05$. Increasing trends are observed at Francistown, Ghanzi, Mahalapye, Sowa Pan and Tsabong. The highest percentage increase in rainfall during the study period was $23.6 \%$ at Francistown. No trend in annual rainfall is reported at Jwaneng. However $57 \%$ of the stations indicate decreasing trends though not significant. The highest decrease in rainfall of $33.5 \%$ is observed at Pandamatenga. The regionalized annual percentage change over the study area indicates a $5.8 \%$ decrease in rainfall. This indicates overall rainfall has decreased across the study area during the period of analysis.

Summer rainfall trends. The summer rainfall exhibits the same trend direction as the annual rainfall with increasing trends reported at Francistown, Ghanzi, Mahalapye and Tsabong. The highest increase in seasonal rainfall of $23.1 \%$ is recorded at Francistown. $71.4 \%$ of the stations show decreasing rainfall trends though none is significant at $\alpha=0.05$. Selibe-Phikwe presented with the highest percentage increase of $35.9 \%$. The study area generally experienced $7.4 \%$ decrease in summer rainfall during the period of study. Spatial distribution of summer rainfall in figure 2(a) indicates decreasing trends in the northern, central 
Table 4. MK trend and Sen's Slope estimator results for rainfall.

\begin{tabular}{|c|c|c|c|c|c|c|}
\hline Station & Season & $\mathrm{p}$-value & MK-Z & Sen's S & Change $(\%)$ & Period of trend analysis \\
\hline \multirow{3}{*}{ Francistown } & Annual & 0.13 & 1.52 & 2.12 & 23.6 & $1960 / 61-2013 / 14$ \\
\hline & Summer & 0.12 & 1.55 & 1.86 & 23.1 & $1960 / 61-2013 / 14$ \\
\hline & Winter & 0.98 & -0.02 & 0.00 & 0.0 & $1960 / 61-2013 / 14$ \\
\hline \multirow[t]{3}{*}{ Ghanzi } & Annual & 0.70 & 0.39 & 0.48 & 5.8 & $1960 / 61-2013 / 14$ \\
\hline & Summer & 0.70 & 0.39 & 0.53 & 7.2 & $1960 / 61-2013 / 14$ \\
\hline & Winter & 0.16 & -1.41 & -0.04 & -26.1 & $1960 / 61-2013 / 14$ \\
\hline \multirow[t]{3}{*}{ Jwaneng } & Annual & 1.00 & 0.00 & 0.60 & 7.1 & $1988 / 89-2013 / 14$ \\
\hline & Summer & 0.97 & -0.04 & -0.30 & -4.0 & $1988 / 89-2013 / 14$ \\
\hline & Winter & 0.91 & -0.11 & -0.03 & -7.4 & $1988 / 89-2013 / 14$ \\
\hline \multirow[t]{3}{*}{ Kasane } & Annual & 0.08 & -1.78 & -3.30 & -25.0 & $1968 / 69-2013 / 14$ \\
\hline & Summer & 0.07 & -1.84 & -3.31 & -26.1 & $1968 / 69-2013 / 14$ \\
\hline & Winter & 0.23 & 1.23 & 0.00 & 0.0 & $1968 / 69-2013 / 14$ \\
\hline \multirow{3}{*}{ Letlhakane } & Annual & 0.70 & -0.39 & -1.28 & -6.8 & $1993 / 94-2013 / 14$ \\
\hline & Summer & 0.39 & -0.88 & -3.22 & -18.7 & $1993 / 94-2013 / 14$ \\
\hline & Winter & $0.03^{*}$ & -2.16 & -0.46 & -58.9 & $1993 / 94-2013 / 14$ \\
\hline \multirow[t]{3}{*}{ Mahalapye } & Annual & 0.85 & 0.19 & 0.29 & 3.4 & $1960 / 61-2012 / 13$ \\
\hline & Summer & 0.88 & 0.15 & 0.17 & 2.3 & $1960 / 61-2012 / 13$ \\
\hline & Winter & 0.60 & -0.52 & -0.02 & -6.4 & $1960 / 61-2012 / 13$ \\
\hline \multirow[t]{3}{*}{ Maun } & Annual & 0.69 & -0.40 & -0.61 & -7.2 & $1960 / 61-2013 / 14$ \\
\hline & Summer & 0.95 & -0.07 & -0.16 & -2.0 & $1960 / 61-2013 / 14$ \\
\hline & Winter & 0.52 & -0.64 & 0.00 & 0.0 & $1960 / 61-2013 / 14$ \\
\hline \multirow[t]{3}{*}{ Pandamatenga } & Annual & 0.17 & -1.40 & -10.84 & -33.5 & $1998 / 99-2013 / 14$ \\
\hline & Summer & 0.27 & -1.13 & -8.70 & -28.6 & $1998 / 99-2013 / 14$ \\
\hline & Winter & 1.00 & -0.05 & 0.00 & 0.0 & $1998 / 99-2013 / 14$ \\
\hline \multirow[t]{3}{*}{ Selibe-Phikwe } & Annual & 0.35 & -0.95 & -8.01 & -34.1 & 1998/99-2013/14 \\
\hline & Summer & 0.27 & -1.13 & -7.52 & -35.9 & $1998 / 99-2013 / 14$ \\
\hline & Winter & $0.03^{*}$ & -2.13 & -0.67 & -96.6 & $1998 / 99-2013 / 14$ \\
\hline \multirow[t]{3}{*}{ Shakawe } & Annual & 0.65 & -0.45 & -0.40 & -4.1 & $1960 / 61-2013 / 14$ \\
\hline & Summer & 0.73 & -0.34 & -0.40 & -4.4 & $1960 / 61-2013 / 14$ \\
\hline & Winter & 0.25 & -1.15 & 0.00 & 0.0 & $1960 / 61-2013 / 14$ \\
\hline \multirow[t]{3}{*}{ SSKA } & Annual & 0.59 & -0.54 & -2.10 & -12.7 & $1985 / 86-2013 / 14$ \\
\hline & Summer & 0.29 & -1.07 & -3.25 & -22.8 & $1985 / 86-2013 / 14$ \\
\hline & Winter & 0.55 & 0.64 & 0.23 & 29.1 & $1985 / 86-2013 / 14$ \\
\hline \multirow[t]{3}{*}{ Sowa Pan } & Annual & 0.96 & 0.06 & 0.39 & 1.9 & $1992 / 93-2009 / 10$ \\
\hline & Summer & 0.96 & -0.06 & -1.39 & -7.4 & $1992 / 93-2009 / 10$ \\
\hline & Winter & 0.06 & -1.85 & -0.51 & -53.4 & 1992/93-2009/10 \\
\hline \multirow[t]{3}{*}{ Tsabong } & Annual & 0.59 & 0.54 & 0.71 & 11.8 & $1960 / 61-2010 / 11$ \\
\hline & Summer & 0.46 & 0.73 & 0.99 & 19.9 & $1960 / 61-2010 / 11$ \\
\hline & Winter & 0.19 & -1.30 & -0.13 & -34.3 & $1960 / 61-2010 / 11$ \\
\hline \multirow[t]{3}{*}{ Tshane } & Annual & 0.13 & -0.56 & -0.71 & -11.2 & $1960 / 61-2013 / 14$ \\
\hline & Summer & 0.72 & -0.36 & -0.37 & -6.7 & $1960 / 61-2013 / 14$ \\
\hline & Winter & 1.00 & 0.00 & 0.00 & 0.0 & $1960 / 61-2013 / 14$ \\
\hline
\end{tabular}

Statistically significant at $\alpha=0.05,{ }^{*}$ significant trends.

and southern locations with a north to south decreasing gradient. There is marginally increasing trends in the west at Ghanzi and southwest at Tshane. Increasing trends are also observed in the east at Francistown.

Winter rainfall trends. Winter rainfall also presents both increasing and decreasing trends.
Increasing trends are reported at Kasane and SSKA, though none was significant. No trend is observed at Tshane during the period of analysis. Decreasing trends are reported in $78.6 \%$ of the stations over the study area with significantly decreasing trends at Letlhakane and Selibe-Phikwe. The percentage decrease at these locations was 59.9 and $96.6 \%$, respectively. The regionalized decrease in winter rainfall over the study area 
Table 5. MK trend and Sen's Slope estimator results for maximum temperature.

\begin{tabular}{|c|c|c|c|c|c|c|}
\hline Station & Season & $\mathrm{p}$-value & MK-Z & Sen's S & Change $(\%)$ & Period of trend analysis \\
\hline \multirow[t]{3}{*}{ Francistown } & Annual & 0.50 & 0.67 & 0.01 & 0.93 & $1980 / 81-2013 / 14$ \\
\hline & Summer & 0.08 & 1.77 & 0.02 & 2.91 & $1960 / 61-2013 / 14$ \\
\hline & Winter & 0.19 & 1.05 & 0.02 & 2.83 & $1984 / 85-2013 / 14$ \\
\hline \multirow[t]{3}{*}{ Ghanzi } & Annual & 0.20 & 1.28 & 0.01 & 1.53 & $1961 / 62-2013 / 14$ \\
\hline & Summer & 0.72 & 0.35 & 0.00 & 0.33 & $1961 / 62-2013 / 14$ \\
\hline & Winter & $0.01^{*}$ & 2.60 & 0.02 & 3.46 & $1961 / 62-2013 / 14$ \\
\hline \multirow[t]{3}{*}{ Jwaneng } & Annual & 0.50 & 0.68 & 0.01 & 1.11 & $1989 / 90-2013 / 14$ \\
\hline & Summer & 0.73 & 0.35 & 0.01 & 0.61 & $1989 / 90-2013 / 14$ \\
\hline & Winter & 0.37 & 0.91 & 0.02 & 1.91 & $1989 / 90-2013 / 14$ \\
\hline \multirow[t]{3}{*}{ Kasane } & Annual & 0.07 & -1.84 & -0.02 & -2.49 & $1983 / 84-2013 / 14$ \\
\hline & Summer & $0.01^{*}$ & -2.65 & -0.03 & -3.10 & $1983 / 84-2013 / 14$ \\
\hline & Winter & 0.34 & -0.95 & -0.01 & -1.49 & $1983 / 84-2013 / 14$ \\
\hline \multirow[t]{3}{*}{ Letlhakane } & Annual & 0.50 & -0.68 & -0.02 & -1.05 & $1994 / 95-2013 / 14$ \\
\hline & Summer & 0.59 & -0.55 & -0.01 & -0.85 & $1994 / 95-2013 / 14$ \\
\hline & Winter & 0.39 & 0.88 & 0.02 & 1.87 & $1994 / 95-2013 / 14$ \\
\hline \multirow[t]{3}{*}{ Mahalapye } & Annual & $0.03^{*}$ & 2.12 & 0.02 & 3.80 & $1971 / 72-2013 / 14$ \\
\hline & Summer & 0.10 & 1.62 & 0.03 & 3.68 & $1971 / 72-2013 / 14$ \\
\hline & Winter & $0.04^{*}$ & 2.04 & 0.02 & 3.16 & $1971 / 72-2013 / 14$ \\
\hline \multirow[t]{3}{*}{ Maun } & Annual & 0.60 & -0.53 & -0.01 & -0.74 & $1980 / 81-2013 / 14$ \\
\hline & Summer & 0.16 & 1.41 & 0.02 & 2.48 & $1965 / 66-2013 / 14$ \\
\hline & Winter & 0.19 & 1.30 & 0.01 & 1.82 & $1980 / 81-2013 / 14$ \\
\hline \multirow[t]{3}{*}{ Pandamatenga } & Annual & 0.76 & 0.32 & 0.02 & 0.93 & 1998/99-2013/14 \\
\hline & Summer & 0.69 & -0.41 & -0.02 & -1.06 & 1998/99-2013/14 \\
\hline & Winter & 0.96 & 0.05 & 0.00 & 0.18 & $1998 / 99-2013 / 14$ \\
\hline \multirow[t]{3}{*}{ Selibe-Phikwe } & Annual & 0.59 & -0.55 & -0.03 & -1.24 & $2000 / 01-2013 / 14$ \\
\hline & Summer & 0.45 & -0.77 & -0.07 & -3.03 & $2000 / 01-2013 / 14$ \\
\hline & Winter & 0.33 & 0.99 & 0.05 & 2.73 & $2000 / 01-2013 / 14$ \\
\hline \multirow[t]{3}{*}{ Shakawe } & Annual & 0.53 & 0.62 & 0.01 & 0.85 & $1980 / 81-2013 / 14$ \\
\hline & Summer & 0.62 & -0.49 & -0.01 & -0.64 & $1980 / 81-2013 / 14$ \\
\hline & Winter & 0.53 & 0.63 & 0.01 & 1.19 & $1985 / 86-2013 / 14$ \\
\hline \multirow[t]{3}{*}{ SSKA } & Annual & 0.16 & -1.41 & -0.03 & -2.71 & $1985 / 86-2013 / 14$ \\
\hline & Summer & 0.26 & -1.14 & -0.03 & -3.08 & $1985 / 86-2013 / 14$ \\
\hline & Winter & 0.12 & -1.56 & -0.03 & -3.29 & $1985 / 86-2013 / 14$ \\
\hline \multirow[t]{3}{*}{ Sowa Pan } & Annual & 1.00 & 0.00 & 0.00 & 0.22 & $1961 / 62-2013 / 14$ \\
\hline & Summer & 0.82 & 0.23 & 0.02 & 0.87 & $1961 / 62-2013 / 14$ \\
\hline & Winter & 0.37 & 0.91 & 0.03 & 2.23 & $1961 / 62-2013 / 14$ \\
\hline \multirow[t]{3}{*}{ Tsabong } & Annual & 0.18 & 1.33 & 0.01 & 1.66 & $1961 / 62-2013 / 14$ \\
\hline & Summer & 0.90 & -0.13 & 0.00 & -0.31 & $1961 / 62-2013 / 14$ \\
\hline & Winter & $0.00^{*}$ & 3.09 & 0.02 & 5.02 & $1961 / 62-2013 / 14$ \\
\hline \multirow[t]{3}{*}{ Tshane } & Annual & 0.22 & 1.23 & 0.01 & 1.31 & $1961 / 62-2013 / 14$ \\
\hline & Summer & 0.62 & -0.50 & -0.01 & -0.86 & $1961 / 62-2013 / 14$ \\
\hline & Winter & 0.89 & -0.14 & 0.00 & -0.23 & $1983 / 84-2013 / 14$ \\
\hline
\end{tabular}

Statistically significant at $\alpha=0.05,{ }^{*}$ significant trends.

is reported at $18.1 \%$. Spatial representation in figure 2(b) indicates a general decrease in winter rainfall with progression from east to west. The highest decrease is concentrated in the central region around Letlhakane. The northeast at Kasane and south at SSKA, increasing trends are observed with no particular gradient to describe the patterns.

\subsubsection{Trends in maximum temperature and percentage changes}

Results showing trends in annual, summer and winter periods are presented in table 5 .

Trends in annual maximum temperature. Results from annual maximum temperature time 
Table 6. MK trend and Sen's Slope estimator results for minimum temperature.

\begin{tabular}{|c|c|c|c|c|c|c|}
\hline Station & Season & p-value & MK-Z & $\begin{array}{l}\text { Sen's } \\
\text { slope }\end{array}$ & $\begin{array}{c}\text { Percentage } \\
\text { change }\end{array}$ & $\begin{array}{c}\text { Period of trend } \\
\text { analysis }\end{array}$ \\
\hline \multirow[t]{3}{*}{ Francistown } & Annual & 0.41 & 0.82 & 0.00 & 2.01 & $1960 / 61-2013 / 14$ \\
\hline & Summer & 0.15 & 1.46 & 0.01 & 2.74 & $1960 / 61-2013 / 14$ \\
\hline & Winter & 0.98 & -0.02 & 0.00 & 0.00 & $1960 / 61-2013 / 14$ \\
\hline \multirow[t]{3}{*}{ Ghanzi } & Annual & $0.00^{*}$ & 3.34 & 0.02 & 8.42 & $1960 / 61-2013 / 14$ \\
\hline & Summer & $0.00^{*}$ & 2.83 & 0.02 & 5.76 & $1960 / 61-2013 / 14$ \\
\hline & Winter & $0.00^{*}$ & 3.17 & 0.03 & 25.48 & $1960 / 61-2013 / 14$ \\
\hline \multirow[t]{3}{*}{ Jwaneng } & Annual & 0.30 & -1.05 & -0.02 & -4.51 & $1989 / 90-2013 / 14$ \\
\hline & Summer & 0.93 & 0.09 & 0.01 & 1.15 & $1989 / 90-2013 / 14$ \\
\hline & Winter & 0.60 & -0.54 & -0.02 & -7.73 & $1989 / 90-2013 / 14$ \\
\hline \multirow[t]{3}{*}{ Kasane } & Annual & 0.58 & -0.56 & -0.01 & -1.84 & $1992 / 93-2013 / 14$ \\
\hline & Summer & 0.70 & 0.39 & 0.00 & 0.52 & $1992 / 93-2013 / 14$ \\
\hline & Winter & 0.12 & -1.58 & -0.04 & -9.67 & $1993 / 94-2013 / 14$ \\
\hline \multirow[t]{3}{*}{ Lethlakane } & Annual & 0.16 & 1.40 & 0.04 & 4.82 & $1994 / 95-2013 / 14$ \\
\hline & Summer & 0.19 & 1.33 & 0.02 & 1.71 & $1994 / 95-2013 / 14$ \\
\hline & Winter & 0.07 & 1.78 & 0.06 & 13.69 & $1994 / 95-2013 / 14$ \\
\hline \multirow[t]{3}{*}{ Mahalapye } & Annual & 0.08 & -1.74 & -0.02 & -4.35 & $1981 / 82-2013 / 14$ \\
\hline & Summer & 0.43 & 0.80 & 0.01 & 3.14 & $1971 / 72-2013 / 14$ \\
\hline & Winter & 0.70 & -0.39 & 0.00 & -2.12 & $1981 / 82-2013 / 14$ \\
\hline \multirow[t]{3}{*}{ Maun } & Annual & $0.01^{*}$ & 2.80 & 0.03 & 5.86 & $1983 / 84-2013 / 14$ \\
\hline & Summer & $0.03^{*}$ & 2.19 & 0.02 & 3.13 & $1983 / 84-2013 / 14$ \\
\hline & Winter & $0.04^{*}$ & 2.09 & 0.04 & 13.84 & $1991 / 92-2013 / 14$ \\
\hline \multirow[t]{3}{*}{ Pandamatenga } & Annual & $0.00^{*}$ & 3.34 & 0.02 & 2.18 & $1998 / 99-2013 / 14$ \\
\hline & Summer & $0.00^{*}$ & 2.83 & 0.02 & 1.64 & $1998 / 99-2013 / 14$ \\
\hline & Winter & $0.00^{*}$ & 3.17 & 0.03 & 4.83 & $1998 / 99-2013 / 14$ \\
\hline \multirow[t]{3}{*}{ Selibe-Phikwe } & Annual & 0.39 & 0.88 & 0.03 & 3.25 & $2000 / 01-2013 / 14$ \\
\hline & Summer & 0.52 & 0.66 & 0.03 & 2.54 & $2000 / 01-2013 / 14$ \\
\hline & Winter & 0.28 & 1.09 & 0.04 & 6.42 & $2000 / 01-2013 / 14$ \\
\hline \multirow[t]{3}{*}{ Shakawe } & Annual & 0.10 & -1.66 & -0.01 & -4.54 & $1965 / 66-2013 / 14$ \\
\hline & Summer & 0.16 & 1.40 & 0.01 & 2.83 & $1965 / 66-2013 / 14$ \\
\hline & Winter & 0.75 & -0.32 & -0.03 & -7.87 & $1991 / 92-2013 / 14$ \\
\hline \multirow[t]{3}{*}{ SSKA } & Annual & 0.42 & -0.81 & -0.01 & -2.76 & $1985 / 86-2013 / 14$ \\
\hline & Summer & 0.84 & 0.21 & 0.00 & 0.49 & $1985 / 86-2013 / 14$ \\
\hline & Winter & 0.20 & -1.29 & -0.02 & -8.72 & $1985 / 86-2013 / 14$ \\
\hline \multirow[t]{3}{*}{ Sowa Pan } & Annual & 0.13 & 1.53 & 0.05 & 4.25 & $1992 / 93-2009 / 10$ \\
\hline & Summer & 0.14 & 1.48 & 0.04 & 3.17 & $1992 / 93-2009 / 10$ \\
\hline & Winter & 0.45 & 0.77 & 0.00 & 0.05 & $1992 / 93-2009 / 10$ \\
\hline \multirow[t]{3}{*}{ Tsabong } & Annual & $0.03^{*}$ & 2.20 & 0.07 & 9.84 & $1996 / 97-2013 / 14$ \\
\hline & Summer & $0.01^{*}$ & 2.62 & 0.08 & 7.71 & $1996 / 97-2013 / 14$ \\
\hline & Winter & $0.01^{*}$ & 2.50 & 0.03 & 42.89 & $1961 / 62-2013 / 14$ \\
\hline \multirow[t]{3}{*}{ Tshane } & Annual & 0.69 & 0.40 & 0.01 & 1.60 & $1988 / 89-2013 / 14$ \\
\hline & Summer & 0.23 & 1.19 & 0.01 & 2.10 & $1981 / 82-2013 / 14$ \\
\hline & Winter & 0.13 & 1.12 & 0.04 & 19.29 & $1987 / 88-2013 / 14$ \\
\hline
\end{tabular}

Statistically significant at $\alpha=0.05,{ }^{*}$ significant trends.

series show decreasing trends at some locations such as Kasane, Letlhakane, Maun, Selebi-Phikwe and SSKA. None of the identified trends were significant with the highest percentage decrease of $2.5 \%$ recorded at Kasane. Sowa Pan recorded no trend in these temperature series. At $57 \%$ of the stations, increasing trends were recorded with significant trends at Mahalapye and a percentage increase of $3.8 \%$ is registered. Regionalized trends indicate that annual maximum temperature has increased by $0.3 \%$ over the period of analysis. Spatial analysis in figure 3(a) indicates that western locations progressing to southwest are experiencing warming trends. Cooling trends are observed in the northeast and south around SSKA. A northeast to southwest 

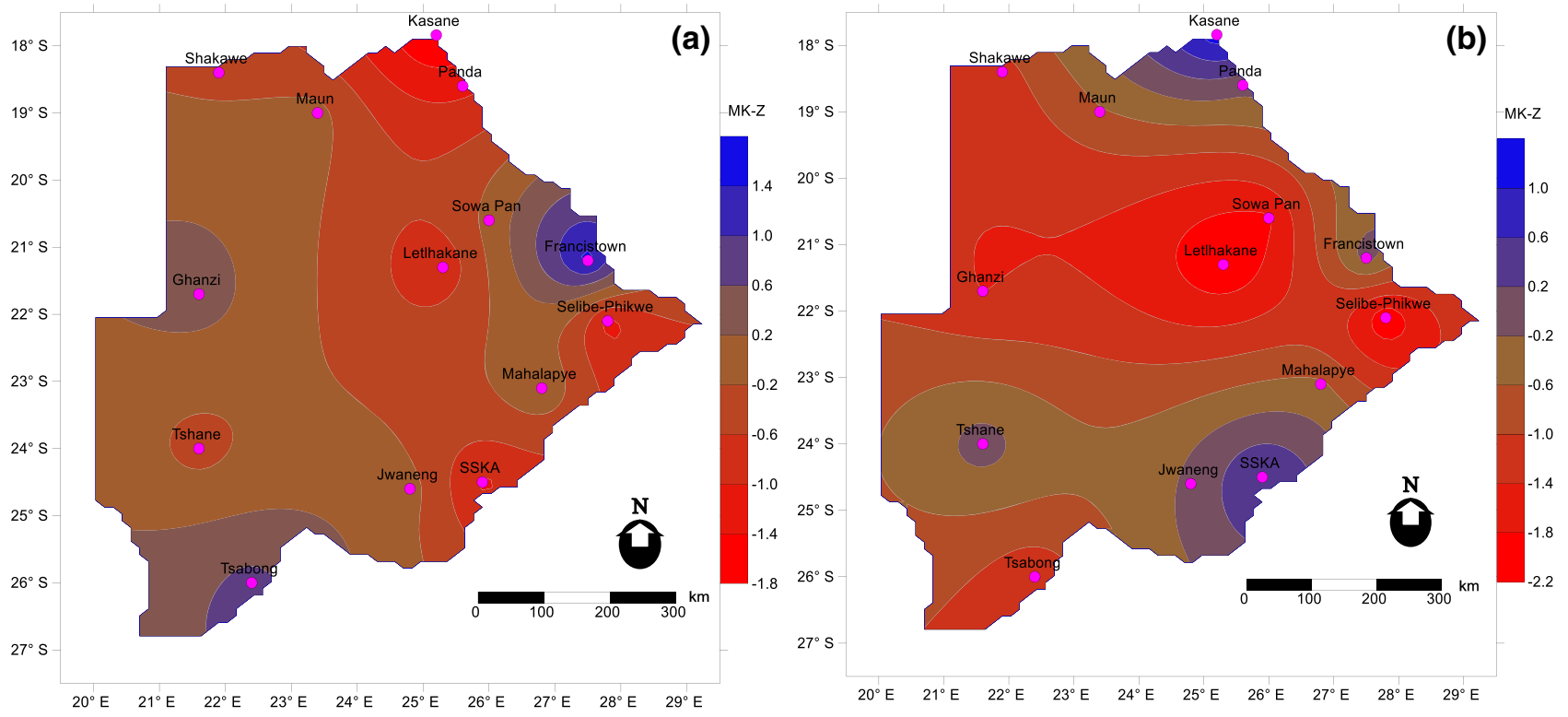

Figure 2. Rainfall MK-Z trends (a) summer and (b) winter.
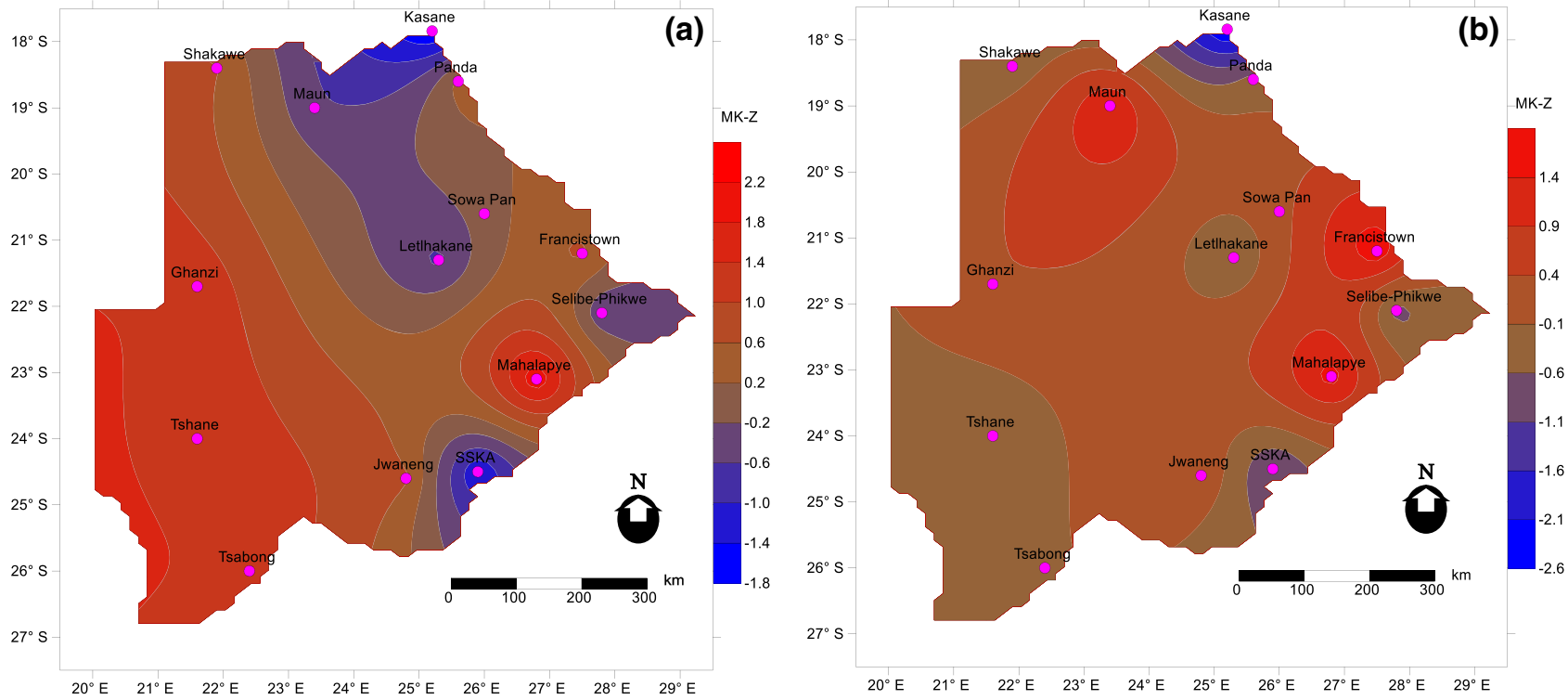

Figure 3. Maximum temperature MK-Z trends (a) annual and (b) summer.

warming gradient is evident from the spatial patterns.

Trends in summer maximum temperature. This climatic variable shows both increasing and decreasing trends. Decreasing trends are observed in $57 \%$ of the stations, but only significant at Kasane with a percentage increase of $3.1 \%$. There are no reported significantly increasing trends over the study area for summer season maximum temperature. The highest percentage increase recorded for summer maximum temperature is $3.7 \%$ at Mahalapye. Overall percentage change shows a reduction by $0.15 \%$ over the study period.
Spatial presentation in figure 3(b) shows the northern and eastern locations present with warming trends. The northeastern locations around Kasane and Pandamatenga show decreasing trends in maximum temperature. The southern locations are generally present with marginal cooling trends. No particular gradient can be established from the spatial patterns which show isolated warming around Maun, Francistown and Mahalapye.

Winter maximum temperature. Decreasing trends in winter maximum temperature are reported at Kasane, SSKA and Tshane though 

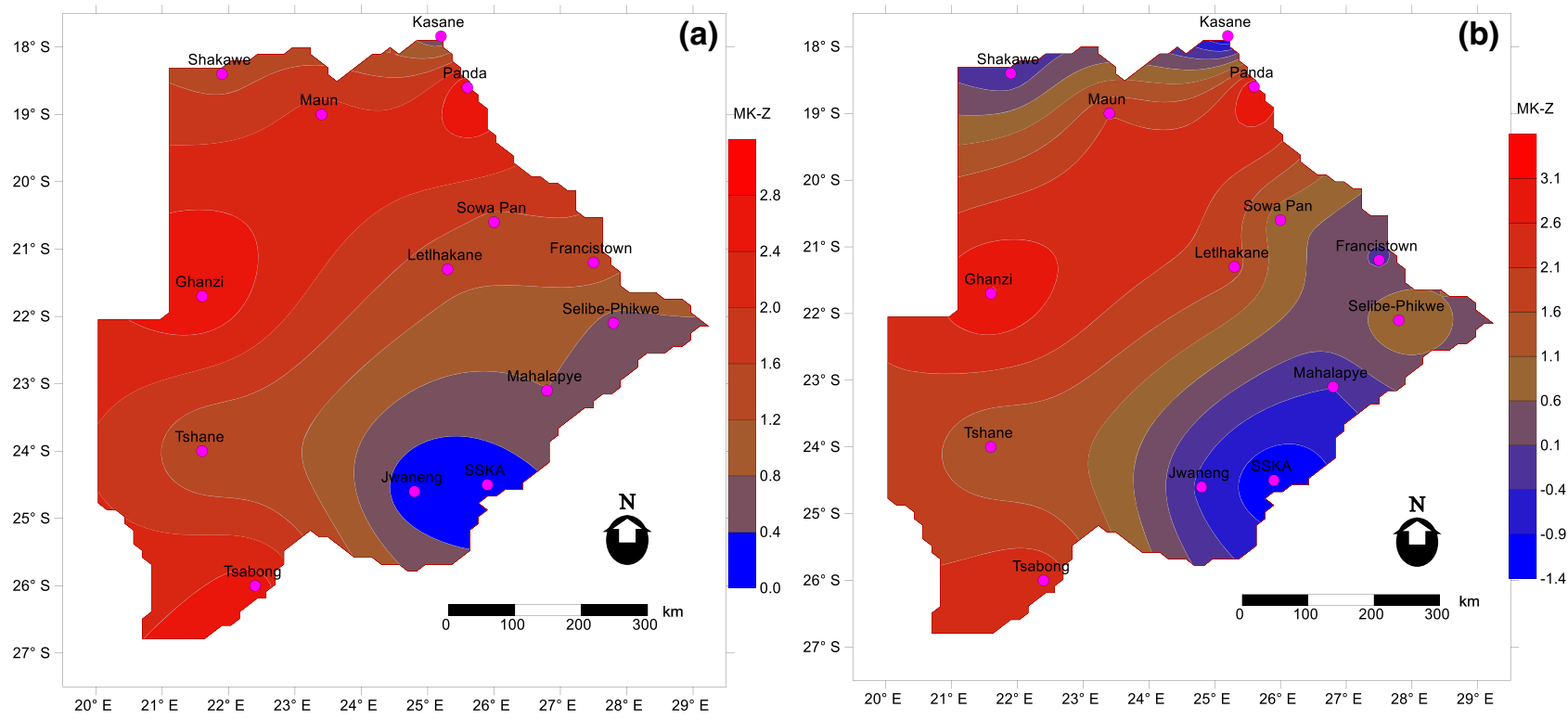

Figure 4. Minimum temperature MK-Z trends (a) summer and (b) winter.

none is significant. The highest percentage decrease of $3.3 \%$ is recorded at SSKA. $78.6 \%$ of the stations recorded generally increasing trends with significant trends registered at Ghanzi and Tsabong. The reported increase at these stations is $3.5 \%$ at Ghanzi and $5.0 \%$ at Tsabong. Overall regional trend indicates an increase of $1.5 \%$ in winter maximum temperature over the study period.

\subsubsection{Trends in minimum temperature and percentage changes}

Results from investigations of long-term trends in minimum temperature at annual and seasonal scales are presented in table 6 .

Trends in annual minimum temperature. Similarly both increasing and decreasing trends are reported in minimum temperature time series at annual scale over the study area. Decreasing trends are observed at Jwaneng, Kasane, Mahalapye and Shakawe though none are significant. The highest decrease of $4.5 \%$ is recorded at Shakawe. $71.4 \%$ of the stations recorded increasing trends with significant trends registered at Ghanzi, Maun, Pandamatenga and Tsabong. The highest increase of $9.8 \%$ is recorded at Tsabong. Regionalized trend indicates an overall increase in annual minimum temperature of $1.7 \%$ across the study area during the period of analysis.
Trends in summer minimum temperature. Summer temperature showed only increasing trends across the study area at all the stations. Significant increase was recorded at Ghanzi, Maun, Pandamatenga and Tsabong. The trends follow similar patterns as those of annual minimum temperature. The highest recorded change in increasing minimum temperature was $7.7 \%$ at Tsabong in the southwest. The regionalized temperature change over the study area indicates increase of $2.7 \%$ during the period of analysis. Spatial representation in figure 4(a) shows increased warming at most locations with large parts in the north, west and east all presenting with warming trends. Marginal trends are observed in the south at SSKA and Jwaneng. A clear warming gradient from east to west is observed from the spatial distribution of summer minimum temperature trends.

Trends in winter minimum temperature. Winter minimum temperature trends equally present with both increasing and decreasing trends. No significantly decreasing trends are registered over the study area. The highest change in decreasing trends is $9.7 \%$ registered at Kasane. $57 \%$ of the stations showed increasing trends in winter minimum temperature. Significantly increasing trends are registered at Ghanzi, Maun, Pandamatenga and Tsabong. The highest change in 


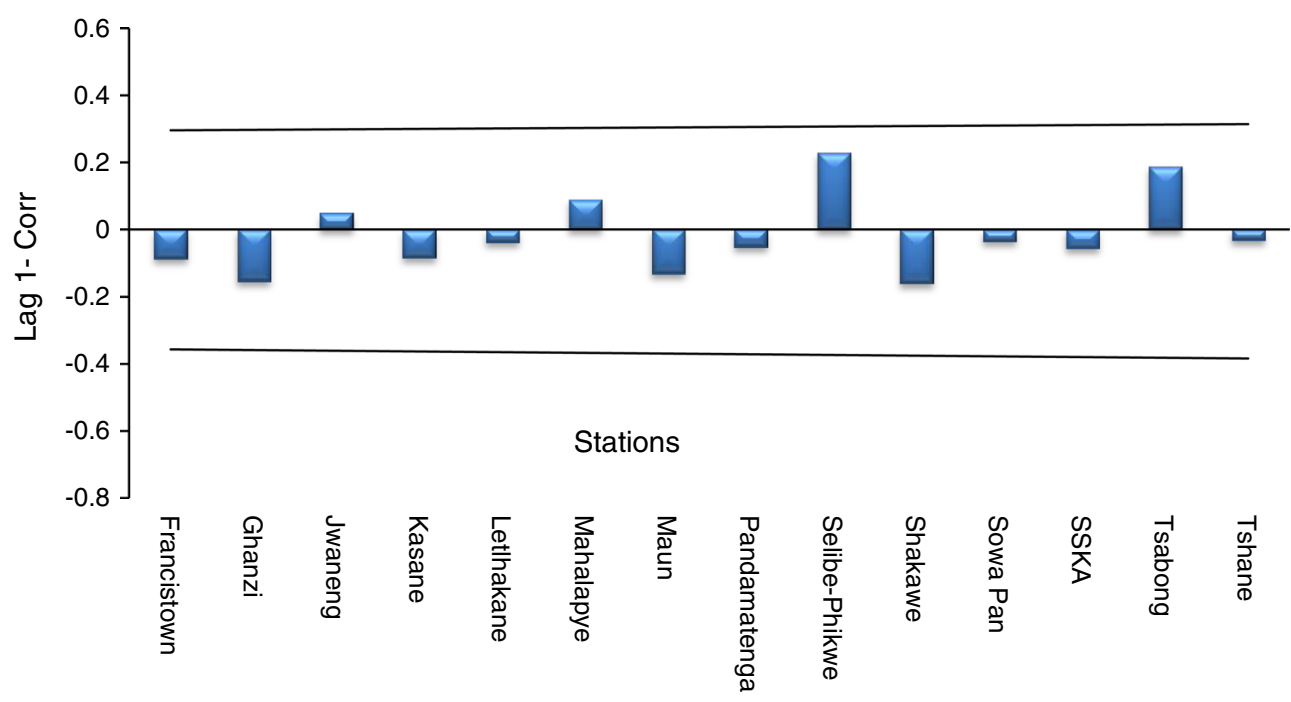

Figure 5. Serial correlation effect on annual rainfall time series.
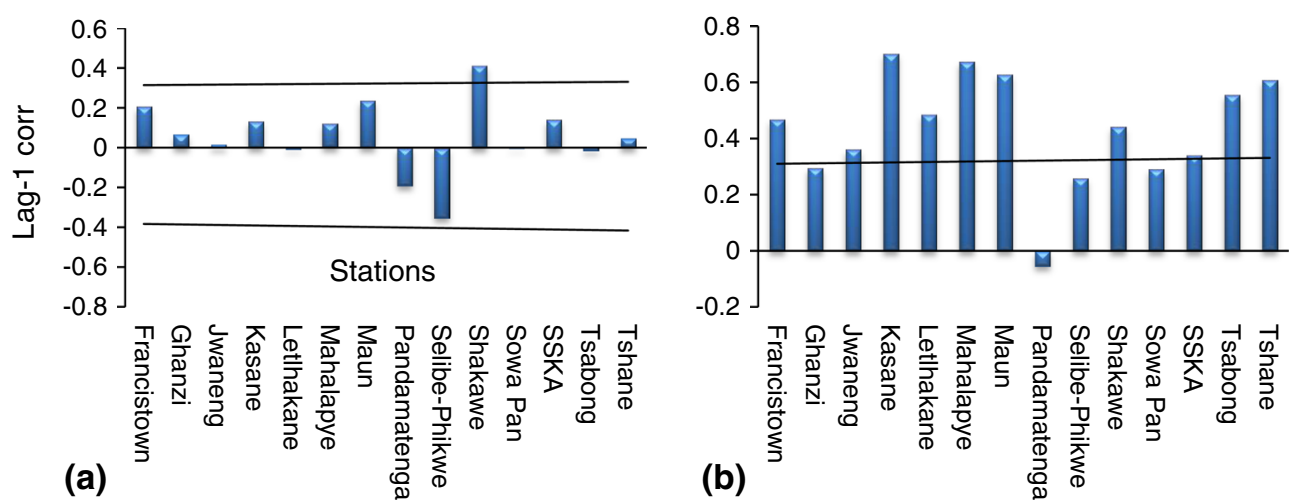

Figure 6. Serial correlation on effect annual (a) maximum and (b) minimum temperature series.

increasing trends was $43 \%$ at Tsabong. Regionally, the trends in minimum temperature are increasing with overall change of $6.5 \%$ during the period of analysis.

Spatial presentation in figure 4(b) indicates warming trends across the study area except for locations in the northeast and northwest at Kasane and Shakawe, respectively. Southern locations of SSKA, Jwaneng and Mahalapye are also showing tendencies of cooling trends. Central, east to west and southwest are showing increasing trends in winter minimum temperature. There are warming gradients observed at three fronts, a gradient is observed from southeast towards the west. Another gradient originates from the northeast, progresses southwards to the west. The final gradient originates from the north progressing southwest. Warming trends are generally concentrated in the west to southwest.

\subsection{Detection of persistence in meteorological time series}

The lag-1 serial correlation of for annual rainfall, maximum and minimum temperature are presented in this section. For the rainfall time series, all the lag-1 serial correlations were nonsignificant at $\alpha=0.05$. Positive serial correlations were obtained at Tsabong, Mahalapye, SelibePhikwe and Jwaneng. Stations with their lag-1 correlations are plotted in figure 5. Maximum temperatures recorded mainly positive correlations with the only negative correlation registered at Pandamatenga and Selibe-Phikwe. Stations presented with mostly none significant lag-1 serial correlations in maximum temperature accept at Shakawe as shown in figure 6(a). The minimum temperature recorded positive correlations at all stations except Pandamentanga. Most of the lag-1 
correlations were significant at $\alpha=0.05$ except for Pandamatenga, Selibe-Phikwe, Jwaneng, Ghanzi and Sowa Pan. The distribution of these stations is shown in figure $6(\mathrm{~b})$.

\subsection{Influence of ENSO on local climatic variables}

Positive correlations resulted from the analysis of rainfall and southern oscillation index (SOI) at both annual and seasonal scales. Significant correlations at annual scale were recorded at $50 \%$ of the stations. During analysis of summer rainfall time series, $43 \%$ of the stations reported significant positive correlations. Winter rainfall registered weak correlations and none are significant.

Negative correlations were observed between rainfall and sea surface temperatures (SSTs) for annual and seasonal time series. Significant negative correlations for both annual and summer series are reported in $43 \%$ of the stations. Winter rainfall time series did not register any significant correlation with SOI in the study area. Correlations between maximum temperature and SOI in annual and seasonal time series were negative at all the stations used in this study. For annual series, significant negative correlations are recorded in $86 \%$ of the stations. The number of stations with significant correlations increased in summer to 93\%. During the winter season, most stations did not record significant correlations except at Maun.

Correlations between maximum temperature and SSTs returned positive correlations for both annual and seasonal series. Significant correlations are registered at $78.5 \%$ of the stations in annual series. From analysis of summer time series, the association is significant at all stations in the study area. Associations with winter maximum time series are not significant most of the time except at Kasane and Mahalapye. Correlations between minimum temperature and SOI over the study area reveal weakly negative associations at annual and winter time scales. The annual minimum temperature associations with SOI are significant at Francistown, Jwaneng and Mahalapye. Associations with winter minimum temperature are significant only at Tsabong. Summer correlations are also significant at $43 \%$ of the stations. Investigations of association between minimum temperature and SSTs reveal significant association at $36 \%$ of the stations at annual scale. During summer season, the number of stations with significant correlations increased to $64 \%$. Winter season correlations are generally not significant except at
Tsabong in southwest. Distribution of stations with significant correlations is presented in figure 7. To further illustrate the influence of ENSO on the local climate, relationships between maximum temperature anomalies and SST from Nino 3.4 are presented in figure 8. The relations are found to be strongest particularly during the years of $1972 / 73,1982 / 83,1997 / 98$ and 2007/08 for both cases of annual and summer season time series.

\section{Discussions}

\subsection{Tests for homogeneity}

The four absolute homogeneity tests demonstrated their ability in detecting inconsistencies and breaks in meteorological time series. The results from these tests have enabled categorization of meteorological stations as 'useful', 'doubtful' and 'suspect'. This is particularly helpful for future climatic studies over the region as station classified as suspect may be excluded from further trend analysis. Results indicated that rainfall time series are fully homogeneous. Similarly, $78.6 \%$ of the stations for maximum temperature and $50 \%$ for minimum temperature time series were found homogeneous. These results of homogenous rainfall series are consistent with findings of Wijngaard et al. (2003) and Hänsel et al. (2016), who indicated difficulties in identifying breaks in rainfall time series with high variability, which is the case for semi-arid climates (Modarres and da Silva 2007). It was easier to detect breaks in temperature time series due to their lower variability as compared to rainfall series. However, in the absence of metadata it was difficult to conclusively state if the reported interventions or lack of them are as a result of climatic changes or inhomogeneities in the time series. For the foregoing reason it was not possible to discard any station, but consciously examine the data before and after the suspected year of intervention. In those stations classified as 'suspect', only those series after the intervention were used in trend analysis.

El Niño years of 1986/87, 1991/92, 1997/98 and $2004 / 05$ at the same time La Niña years of $1983 / 84$ and $1984 / 85$ were also identified as years of intervention in the temperature time series. This revelation may further strengthen the assertion that inter-annual variability over southern Africa 


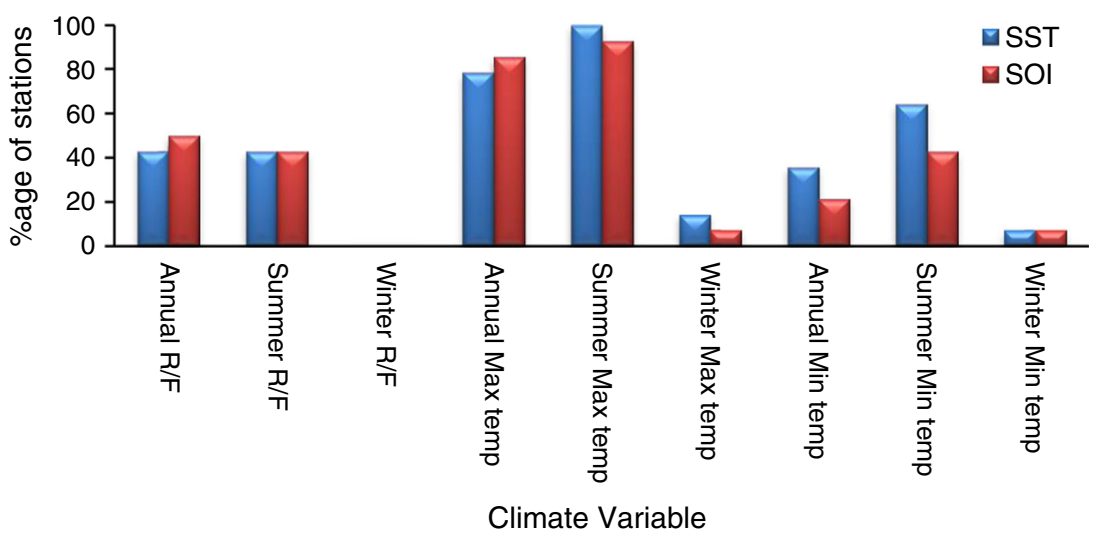

Figure 7. Proportions of stations with significant correlation between ENSO and local climatic variables.
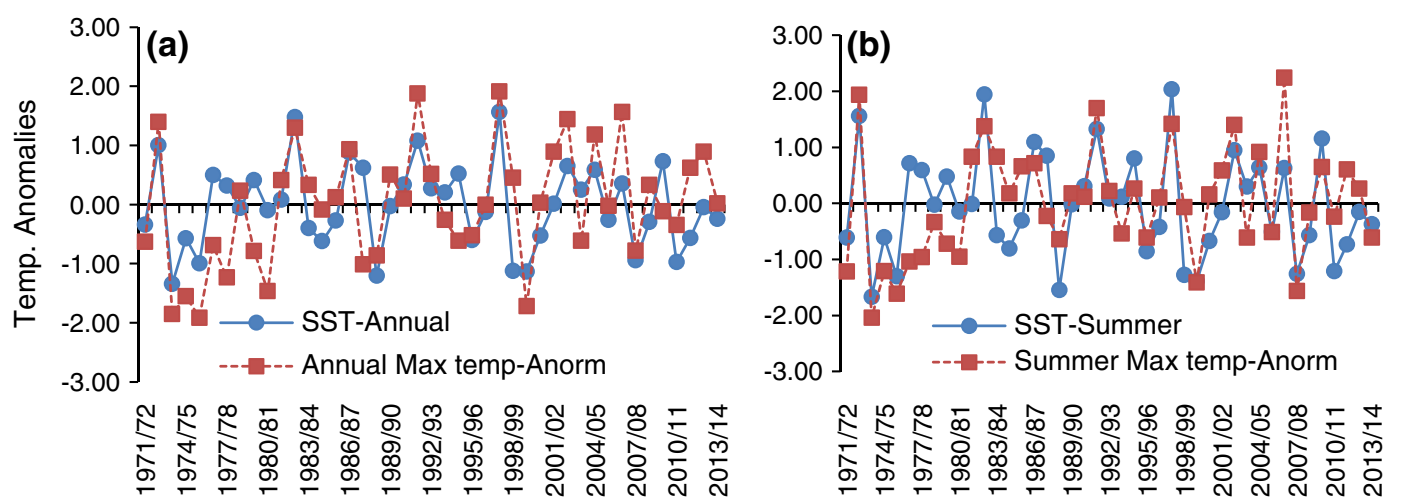

Figure 8. Maximum temperature normalized at Mahalapye and Nino 3.4 SST time series (a) annual and (b) summer.

is influenced by ENSO activities in the Equatorial Pacific that has been reported in Nicholson et al. (2001), Usman and Reason (2004) and Edossa et al. (2014). The rest of the intervention years are either immediately before or after a given El Niño or La Niña event.

\subsection{Mann-Kendall trend analysis and percentage change}

\subsubsection{Trends in rainfall time series}

From the results, it was evident that summer seasonal rainfall patterns were similar to annual series. This could be attributed to the fact that summer rainfall contributes more than $90 \%$ of the total annual rainfall received over the study area (Batisani and Yarnal 2010). Decreasing trends in annual and summer rainfall could pose a threat to Botswana's water and agricultural resources. This is envisaged because most of the negative trends are reported in Shakawe, Maun and Kasane located in the Okavango basin, a Ramsar heritage site that moderates local climate (Byakatonda et al. 2016). The other locations SSKA, and Selibe-Phikwe lies in the Limpopo basin that hosts majority of surface dams that supply most of the water needs for both industrial and irrigation. Spatial trends in annual and summer rainfall indicate decreasing amounts from northeast at Kasane to central around Letlhakane progressing southward to SSKA. Winter rainfall patterns are unrelated with annual and summer rainfall with locations showing significantly decreasing trends at Letlhakane and SelibePhikwe. Winter rainfall may not be relied upon since it accounts for less than $10 \%$ of annual rainfall. Overall there is a decrease in rainfall amounts over the study area of 5.8, 7.4 and $18.1 \%$ during annual, summer and winter, respectively.

\subsubsection{Trends in maximum temperature time series}

Annual trends indicate that locations bordering Kalahari Desert such as Shakawe, Ghanzi, and Tsabong are experiencing warming trends. The northern locations of Maun, Kasane and Pandamatenga are showing cooling trends, which could favour agricultural activities in these locations due to reduced evapotranspiration rates. Mahalapye 
located in the Limpopo basin is experiencing warming trends which could increase evaporation rates from surface reservoirs.

Summer maximum temperature also indicates warming trends for the locations bordering the Kalahari Desert. The Okavango and Limpopo basins are still at threat with warming trends at Mahalapye. High evaporation rates during summer could be more severe since most of the moisture supply is available during this season.

Winter maximum temperature is exhibiting similar patterns during annual and summer season trends with western locations experiencing warming trends during the winter season. Overall there is a regionalized increase in annual and winter maximum temperature of 0.3 and $1.5 \%$, respectively.

\subsubsection{Trends in minimum temperature time series}

Annual and winter minimum temperature patterns showed similar direction with the south and northern locations exhibiting decreasing trends. Locations near the Kalahari Desert progressing to central through to northeast at Pandamatenga are all experiencing warming trends. There is a generally warming climate over the study area with a change of 1.7 and $6.5 \%$ during annual and winter periods, respectively. Warming during winter may not pose much threat since there is little moisture to be evaporated.

During the summer season, majority of the study area becomes warmer with an east to west increasing gradient towards the Kalahari Desert. Summer being an important season in Botswana characterized by rains, reported warming may be an indicator that effects of global warming reported in Pachauri and Reisinger (2007) and Stocker et al. (2013) are already being felt in the study area.

Decreasing trends in rainfall and increasing temperature across the study area could be a sign of increasing aridity. It has been reported earlier that as the climate becomes drier, it is associated with high climate variability due to limited moisture supply and high evaporation rates (Modarres and da Silva 2007; Reza et al. 2011; Recha et al. 2012; Omoyo et al. 2015). Rainfall is already highly variable as indicated by coefficients of variation (CVs) of more than $25 \%$ across the study area. This could be an indication that Botswana's climate is becoming more variable.

\subsection{Detection of persistence}

Rainfall time series, which were reported to be homogeneous, also appear to be independent. The maximum temperature series are also independent except at Shakawe. Minimum temperature shows a number of stations with significantly dependent time series. The distribution of the stations in the study area has no specific spatial pattern. Those stations whose series were found to be dependent, the effective sample size technique was applied to adjust the $Z$-statistic obtained from the MK trend analysis.

\subsection{Influence of ENSO on local climatic variables}

Significant positive correlations between rainfall and SOI and negative correlations between rainfall and SSTs demonstrate the association of local rainfall with ENSO events. Earlier studies by Kenabatho et al. (2012) had indicated negative correlations between rainfall and local temperature. Coupled with highly positive correlations between local temperature and SSTs, it is evident that ENSO events influence rainfall patterns over the study area. Winter correlations are relatively weaker than those at annual and summer scales, which could be pointing to the fact that ENSO has more influence on the local climate during summer season. Similar studies on the influences of ENSO on local climate in other semiarid environments such as Iran reported similar order of magnitudes in correlations with opposite signs (Nazemosadat et al. 2006; Tabari and Talaee 2011). This could be attributed to the location of Iran in northern hemisphere as compared to Botswana.

Temperature time series presents with negative correlations with SOI and positive with SSTs, a similar association between SSTs and SOI. Correlations were higher with maximum temperature as compared to minimum temperature. This could imply that maximum temperature has more influence on local climate than minimum temperature. In this case maximum temperature can act as a potential indicator of ENSO impacts on local climate.

To further illustrate the close interaction between maximum temperature and ENSO signal, figure 8 indicates that relationship between SSTs and maximum temperature became stronger during El Niño years of 1972/73, 1982/83, 1997/98 and La Niña year of 2007/08. During the El Niño years, 
positive anomalies, which are responsible for droughts conditions over southern Africa are evident and during the La Niña years, negative anomalies are observed on the plot accounting for wet conditions over the region.

The ENSO phenomenon has been known to propagate climate variability due to uncertainties associated with these events (Kandji et al. 2006; Dai 2013; Morán-Tejeda et al. 2016). During El Niño events, rains in the southern Africa region dip to below long-term mean leading to severe and prolonged droughts (Nicholson et al. 2001; Usman and Reason 2004), whereas during the La Niña episodes, flood causing heavy rains that lead to destruction of infrastructure are recorded as above normal. These fluctuations resulting from anomalies in SSTs coupled with local feedbacks have increased climate variability and global aridity (Dai 2011a; Huang et al. 2016). With high correlations reported and close relationships observed during the period of study, this could be another pointer towards high variable climate across the study area. The local feedbacks are mainly linked with warming of the Indian Ocean in telecommunication with positive SST anomalies in the Equatorial Pacific, especially during austral summer (Nicholson et al. 2001; Jury 2002). It is during the summer season that more than $90 \%$ of the stations showed significant correlations with ENSO. The plots in figure 8 have demonstrated close relationships between ENSO and local climatic variables during years for which extreme events were recorded in the southern African region. One of such events is the severe El Niño drought of $1982 / 83$ with SST anomalies raising above $6^{\circ}$ that affected economies of regional member states (Dai 2011b; Jury 2013). Another event is the La Niña heavy rains of $1999 / 2000$, which caused devastating floods in Mozambique with pests and disease outbreak in Botswana that resulted in 50\% crop yield decline in that year (Kandji et al. 2006). This study has demonstrated that local climate is still influenced by the large climatic predictors associated with high climate variability.

\section{Conclusions and summary}

Climate variability and change in Botswana was investigated through annual and seasonal time series of rainfall, maximum and minimum temperature for a period 1960-2014. Four absolute homogeneity tests were used to check any possible inhomogeneities and interventions in the time series. The Mann-Kendall and Sen's Slope estimator were used to detect trends and absolute changes over the period of study at 14 synoptic stations. The association of local climatic variables with ENSO was also investigated through multivariate correlation analysis. The following summary has been deduced from the study.

- The rainfall time series are fully homogeneous across the study period at all the stations. $78.6 \%$ of the stations for maximum temperature and $50 \%$ of the stations for minimum temperature were homogeneous, classifying as 'useful'. Due to absence of metadata, it was not possible to conclude if the presence of homogeneous time series or lack of them was as a result of inhomogeneities or normal climate regime shift. Most of the years of intervention identified also either coincided with El Niño/La Niña or closely followed and at times preceded ENSO episodes.

- Trends in rainfall indicate a general decrease of 5.8, 7.4 and $18.1 \%$ during annual, summer and winter seasons over the study area, respectively. There is a regionalized warming trend of 0.3 and $1.5 \%$ in annual and winter maximum temperature, respectively. Minimum temperature also reported warming trends of 1.7 and $6.5 \%$ during annual and winter season in the study area. The decreasing trends in rainfall and warming trends across Botswana could lead to more climate variability.

- The rainfall time series were completely random with only temperature series showing some persistence at some stations. Maximum temperature time series are found to be random except at Shakawe. $57 \%$ of the stations showed persistence tendencies in minimum temperature. The effective sample size technique was used to adjust the $Z$-statistic from the MK analysis for stations with persistence.

- Significant positive correlations exist between rainfall and SOI, at the same time rainfall is negatively associated with SSTs. More significant positive associations are identified between SST and maximum temperature. The associations were particularly strong during the summer season with very close relationships established between local climatic variables and ENSO during El Niño years of 1972/73, 1982/83, 1997/98 and La Niña years of 2007/08. The significant correlations between local climate and ENSO 
could further be linking Botswana's climate with high variability due to uncertainties that are associated with ENSO events.

In general, the study reveals decreasing rainfall amounts and warming trends across the study area. The influence of ENSO on local climate has been established linking Botswana to high climate variability. Information generated by this study could be beneficial to agricultural and water resources planning and management especially in semi-arid environments, where adaptability to climate variability and change is still low.

\section{Acknowledgements}

This study was supported by the Mobility for Engineering Graduates in Africa (METEGA) and Carnegie Cooperation of New York through RUFORUM in the form of research funds. The climatic data used were provided by Department of Meteorological Services (DMS) of Botswana. The authors are grateful for the support from the two entities. Gulu University is highly appreciated for granting study leave to the first author. They also wish to thank the two anonymous reviewers for their valuable comments that enriched this study.

\section{References}

Akinsanola A A and Ogunjobi K O 2015 Recent homogeneity analysis and long-term spatio-temporal rainfall trends in Nigeria; Theor. Appl. Climatol. 128 275-289, https://doi. org/10.1007/s00704-015-1701-x.

Alexandersson H 1986 A homogeneity test applied to precipitation data; J. Climatol. 6 661-675.

Alexandersson $\mathrm{H}$ and Moberg A 1997 Homogenization of Swedish temperature data. Part I: Homogeneity test for linear trends; Int. Int. J. Climatol. 17 25-34.

Batisani N 2012 Climate variability, yield instability and global recession: The multi-stressor to food security in Botswana; Clim. Dev. 4 129-140.

Batisani N and Yarnal B 2010 Rainfall variability and trends in semi-arid Botswana: Implications for climate change adaptation policy; Appl. Geogr. 30 483-489.

Buishand T A 1982 Some methods for testing the homogeneity of rainfall records; J. Hydrol. 58 11-27.

Byakatonda J, Parida B P, Kenabatho P K and Moalafhi D B 2016 Modeling dryness severity using artificial neural network at the Okavango Delta, Botswana; Glob. Nest. J. 18 463-481.

Costa A C and Soares A 2009a Trends in extreme precipitation indices derived from a daily rainfall database for the south of Portugal; Int. J. Climatol. 29 1956-1975.
Costa A C and Soares A 2009b Homogenization of climate data: Review and new perspectives using geostatistics; Math. Geosci. 41 291-305, https://doi.org/10.1007/ s11004-008-9203-3.

Croakin C and Tobias P 2006 NIST/SEMATECH eHandbook of Statistical Methods, National Institute of Standards and Technology/SEMATECH; US Commerce Department's Technology Administration.

Dai A 2013 Increasing drought under global warming in observations and models; Nat. Clim. Change 3 52-58.

Dai A 2011a Drought under global warming: A review; Wiley Interdiscip. Rev. Clim. Change 2 45-65, https://doi.org/ 10.1002 /wcc. 81 .

Dai A 2011b Characteristics and trends in various forms of the Palmer Drought Severity Index during 1900-2008.

Edossa D C, Woyessa Y E and Welderufael W A 2014 Analysis of droughts in the central region of South Africa and their association with SST anomalies; Int. J. Atmos. Sci., https://doi.org/10.1155/2014/508953.

Giorgi F and Lionello P 2008 Climate change projections for the Mediterranean region; Global Planet. Change $\mathbf{6 3}$ 90-104.

Gocic M and Trajkovic S 2013 Analysis of changes in meteorological variables using Mann-Kendall and Sen's slope estimator statistical tests in Serbia; Global Planet. Change 100 172-182, https://doi.org/10.1016/j.gloplacha.2012. 10.014 .

Hänsel S, Medeiros D M and Matschullat J et al. 2016 Assessing homogeneity and climate variability of temperature and precipitation series in the capitals of north-eastern Brazil; Front. Earth Sci. 4 1-21, https://doi.org/10.3389/ feart.2016.00029.

Hansen J, Sato M and Ruedy R et al. 2016 Global Temperature in 2015; Colomb. Univ., pp. 1-6.

Huang J, Ji M and Xie Y et al. 2016 Global semi-arid climate change over last 60 years; Clim. Dyn. 46 1131-1150.

Jury M R 2002 Economic impacts of climate variability in South Africa and development of resource prediction models; J. Appl. Meteorol. 41 46-55.

Jury M R 2013 Climate trends in southern Africa; S. Afr. J. Sci. 109 1-11.

Kandji S T, Verchot L and Mackensen J 2006 Climate change climate and variability in southern Africa: Impacts and adaptation in the agricultural sector; World Agroforestry Centre (ICRAF), United Nations Environment Programme (UNEP), Africa.

Kenabatho P K, Parida B P and Moalafhi D B 2012 The value of large-scale climate variables in climate change assessment: The case of Botswana's rainfall; Phys. Chem. Earth 50-52 64-71, https://doi.org/10.1016/j.pce.2012. 08.006 .

Kendall M G 1975 Rank Correlation Methods; 4th edn, London.

Khan M I, Liu D and Fu Q et al. 2016 Recent climate trends and drought behavioral assessment based on precipitation and temperature data series in the Songhua River Basin of China; Water Resour. Manag. 30 4839-4859.

Lettenmaier D P 1976 Detection of trends in water quality data from records with dependent observations; Water Resour. Res. 12 1037-1046.

Mann H B 1945 Nonparametric tests against trend; Econom. J. Econom. Soc. 13(3) 245-259. 
Matalas N C and Langbein W B 1962 Information content of the mean; J. Geophys. Res. 67 3441-3448.

Menzel A, Sparks T H and Estrella N et al. 2006 European phenological response to climate change matches the warming pattern; Glob. Change Biol. 12 19691976 .

Modarres R and da Silva V de P R 2007 Rainfall trends in arid and semi-arid regions of Iran; J. Arid Environ. 70 344-355.

Morán-Tejeda E, Bazo J and López-Moreno J I et al. 2016 Climate trends and variability in Ecuador (1966-2011); Int. J. Climatol.https://doi.org/10.1002/joc.4597.

Nazemosadat M J, Samani N, Barry D A and Niko M M 2006 ENSO forcing on climate change in Iran: Precipitation analysis; Iran. J. Sci. Technol. Trans. B Eng. 30 $1-11$.

Nicholson S E, Leposo D and Grist J 2001 The relationship between El Niño and drought over Botswana; J. Clim. 14 323-335.

NOAA-NCDC 2016 Southern Oscillation Index (SOI); www. ncdc.noaa.gov/teleconnections/enso/indicators/soi/data. csv.

NOAA-NCEP 2016 Average sea surface temperature (SST) anormalies in region 3.4 of the Equatorial Pacific. http://www.cpc.ncep.noaa.gov/products/ analysis_monitoring/ensostuff/ONI_change.shtml.

Nyenzi B and Lefale P F 2006 El Niño Southern Oscillation (ENSO) and global warming; Adv. Geosci. 6 95-101.

Omoyo N N, Wakhungu J and Oteng'i S 2015 Effects of climate variability on maize yield in the arid and semi arid lands of lower eastern Kenya; Agric. Food Secur. 48 , https://doi.org/10.1186/s40066-015-0028-2.

Pachauri R K and Reisinger A 2007 IPCC fourth assessment report; IPCC, Geneva.

Parida B P and Moalafhi D B 2008 Regional rainfall frequency analysis for Botswana using L-Moments and radial basis function network; Phys. Chem. Earth 33 614-620, https://doi.org/10.1016/j.pce.2008.06.011.

Partal T and Kahya E 2006 Trend analysis in Turkish precipitation data; Hydrol. Process. 20 2011-2026, https:// doi.org/10.1002/hyp.5993.

Pettit A N 1979 A non-parametric approach to the changepoint detection; Appl. Stat. 28 126-135.

Rahman M R and Lateh H 2017 Climate change in Bangladesh: A spatio-temporal analysis and simulation of recent temperature and rainfall data using GIS and time series analysis model; Theor. Appl. Climatol. 128 27-41, https://doi.org/10.1007/s00704-015-1688-3.

Recha C W, Makokha G L and Traore P S et al. 2012 Determination of seasonal rainfall variability, onset and cessation in semi-arid Tharaka district, Kenya; Theor. Appl. Climatol. 108 479-494.

Reza Y M, Javad K D, Mohammad M and Ashish S 2011 Trend detection of the rainfall and air temperature data in the Zayandehrud basin; J. Appl. Sci. 11 2125-2134.
Rojas O, Li Y and Cumani R 2014 An assessment using FAO's Agricultural Stress Index (ASI): Understanding the drought impact of El Niño on the global agricultural areas.

Sabzevari A A, Zarenistanak M, Tabari H and Moghimi S 2015 Evaluation of precipitation and river discharge variations over southwestern Iran during recent decades; $J$. Earth Syst. Sci. 124 335-352, https://doi.org/10.1007/ s12040-015-0549-x.

Sen P K 1968 Estimates of the regression coefficient based on Kendall's tau; J. Am. Stat. Assoc. 63 1379-1389.

Shahid S 2010 Rainfall variability and the trends of wet and dry periods in Bangladesh; Int. J. Climatol. 30 2299-2313, https://doi.org/10.1002/joc.2053.

Shifteh Some'e B, Ezani A and Tabari H 2012 Spatiotemporal trends and change point of precipitation in Iran; Atmos. Res. 113 1-12, https://doi.org/10.1016/j. atmosres.2012.04.016.

Statistics Botswana 2009 Botswana water statistics; Gaborone, Botswana.

Statistics Botswana 2015 Statistics Botswana Annual Agricultural Survey Report 2013, Gaborone, Botswana.

Stocker T F, Qin D and Plattner G K et al. 2013 Climate change 2013: The physical science basis; Intergovernmental panel on climate change, working group I contribution to the IPCC fifth assessment report (AR5).

Tabari H, Somee B S and Zadeh M R 2011 Testing for long-term trends in climatic variables in Iran; Atmos. Res. 100 132-140, https://doi.org/10.1016/j.atmosres. 2011.01.005.

Tabari H and Talaee P H 2011 Temporal variability of precipitation over Iran: 1966-2005; J. Hydrol. 396 313-320, https://doi.org/10.1016/j.jhydrol.2010.11.034.

Thiel H 1950 A rank-invariant method of linear and polynomial regression analysis, Part 3. In: Proceedings of Koninalijke Nederlandse Akademie van Weinenschatpen A, pp. 1397-1412.

Usman M T and Reason C J C 2004 Dry spell frequencies and their variability over southern Africa; Clim. Res. 26 199-211, https://doi.org/10.3354/cr026199.

Von Neumann J 1941 Distribution of the ratio of the mean square successive difference to the variance; Ann. Math. Stat. 12 367-395.

Wijngaard J B, Klein Tank A M G and Können G P 2003 Homogeneity of $20^{\text {th }}$ century European daily temperature and precipitation series; Int. J. Climatol. 23 679-692, https://doi.org/10.1002/joc.906.

Yue S and Hashino M 2003 Long Term Trends of Annual and Monthly Precipitation in Japan; JAWRA J. Am. Water. Resour. Assoc. 39 587-596, https://doi.org/10. 1111/j.1752-1688.2003.tb03677.x.

Yue S, Pilon P, Phinney B and Cavadias G 2002 The influence of autocorrelation on the ability to detect trend in hydrological series; Hydrol. Process 16 1807-1829, https://doi.org/10.1002/hyp.1095. 